\title{
Arbeidsmarktmonitor chemische sector
}

Citation for published version (APA):

Cörvers, F., \& Golsteyn, B. H. H. (2005). Arbeidsmarktmonitor chemische sector. Researchcentrum voor Onderwijs en Arbeidsmarkt, Faculteit der Economische Wetenschappen. ROA Reports No. 3

https://doi.org/10.26481/umarep.2005003

Document status and date:

Published: 01/01/2005

DOI:

10.26481/umarep.2005003

Document Version:

Publisher's PDF, also known as Version of record

\section{Please check the document version of this publication:}

- A submitted manuscript is the version of the article upon submission and before peer-review. There can be important differences between the submitted version and the official published version of record.

People interested in the research are advised to contact the author for the final version of the publication, or visit the DOI to the publisher's website.

- The final author version and the galley proof are versions of the publication after peer review.

- The final published version features the final layout of the paper including the volume, issue and page numbers.

Link to publication

\footnotetext{
General rights rights.

- You may freely distribute the URL identifying the publication in the public portal. please follow below link for the End User Agreement:

www.umlib.nl/taverne-license

Take down policy

If you believe that this document breaches copyright please contact us at:

repository@maastrichtuniversity.nl

providing details and we will investigate your claim.
}

Copyright and moral rights for the publications made accessible in the public portal are retained by the authors and/or other copyright owners and it is a condition of accessing publications that users recognise and abide by the legal requirements associated with these

- Users may download and print one copy of any publication from the public portal for the purpose of private study or research.

- You may not further distribute the material or use it for any profit-making activity or commercial gain

If the publication is distributed under the terms of Article $25 \mathrm{fa}$ of the Dutch Copyright Act, indicated by the "Taverne" license above, 


\section{Arbeidsmarktmonitor chemische sector}

ROA-R-2005/3

Frank Cörvers

Bart Golsteyn

Researchcentrum voor Onderwijs en Arbeidsmarkt

Faculteit der Economische Wetenschappen en Bedrijfskunde Universiteit Maastricht

Maastricht, februari 2005 
ISBN 90-5321-420-8

Sec05.015.doc 


\section{Inhoud}

Bladzijde

1 Introductie en samenvatting 1

2 Data en definities 5

3 De arbeidsmarktpositie van afgestudeerden met een opleiding in de chemie

3.1 Arbeidsmarktindicatoren 2003

3.2 Ontwikkeling van arbeidsmarktindicatoren vanaf $1996 \quad 10$

4 De vraag naar arbeidskrachten door werkgevers $\quad 17$

5 Conclusies en aanbevelingen voor vervolgonderzoek 33 



\section{Introductie en samenvatting}

Berichtgeving in de media en cijfermateriaal verzameld door de Vereniging van de Nederlandse Chemische Industrie ( $\mathrm{VNCl}$ ) en de Koninklijke Nederlandse Chemische Vereniging (KNCV) met betrekking tot de arbeidsmarktsituatie in de chemische sector hebben geleid tot een paradoxaal beeld. ${ }^{1}$ Aan de vraagkant lijkt er een tekort aan chemici te zijn waarbij het aantal afgestudeerden niet voldoende is om degenen die met pensioen gaan te vervangen. Aan de aanbodkant kampen pas afgestudeerden met werkloosheid en moeten ze concurreren met veel andere sollicitanten voor een vacature, wat juist duidt op een overschot aan chemici. In dit rapport zal nieuw licht worden geworpen op deze paradox door genuanceerder de informatie van vraag en aanbod te analyseren.

Uitgangspunt in het onderzoek is dat een overschot of tekort aan chemici niet eenvoudig vast te stellen is door het vergelijken van bijvoorbeeld het aantal afgestudeerden met een opleiding chemie ten opzichte van het aantal nieuwe vacatures in een sector. Dit komt doordat vraag en aanbod voor een bepaalde sector niet eenvoudig te definiëren zijn. Aanbodoverschotten of -tekorten zijn moeilijk te meten met het werkloosheidscijfer omdat chemici die geen baan vinden ook andere concessies kunnen doen dan werkloos blijven, zoals het accepteren van een baan buiten hun richting of onder hun niveau. Vraagtekorten of -overschotten zijn om dezelfde reden niet eenvoudigweg te meten met vacaturecijfers. Als er tekorten zijn kunnen werkgevers ook schoolverlaters uit andere opleidingsrichtingen in dienst nemen, een hoger loon bieden, personeel werven in het buitenland, etc. Zowel aan de aanbodzijde als aan de vraagzijde gaan dergelijke concessies gepaard met aanpassingskosten. Om een indruk te krijgen van de verhouding tussen vraag en aanbod op het arbeidsmarktsegment van de chemie is het belangrijk om de concessies die beide partijen hebben gedaan met betrekking tot de personeelswerving respectievelijk het vinden van een baan te analyseren.

In dit rapport zullen daarom de arbeidsmarktpositie van afgestudeerden met een opleiding in de chemie en de personeelswerving door werkgevers in de chemische industrie apart worden onderzocht. Op die manier komt niet alleen aan het licht of werkgevers knelpunten ondervinden bij het aantrekken van personeel of afgestudeerden moeite hebben om een geschikte baan te vinden, maar ook welke stappen men vervolgens neemt om zich aan te passen aan de arbeidsmarktsituatie waarmee men wordt geconfronteerd.

De analyse onder afgestudeerden van het hoger onderwijs (HBO en WO) had betrekking op de periode 1996-2003. Er is voor de afgestudeerden in deze periode gekeken:

- Of zij anderhalf jaar na afstuderen werkloos zijn,

1. Zie artikel 'Tekort aan chemie studenten? Het zijn er juist te veel' (Chemisch weekblad, april 2004). 
- Of zij te maken hebben gehad met intredewerkloosheid (werkloos tussen afstuderen en eerste baan),

- Hoe lang zij werkloos zijn geweest na de studie,

- Of zij een baan op hun niveau hebben gevonden,

- Of zij een baan in hun richting hebben gevonden,

- Het gemiddelde loon.

Voor de werkgevers in de chemische industrie is voor het jaar 2001 gekeken naar:

- $\quad$ Of men (moeilijk vervulbare) vacatures heeft en zo ja, hoeveel vacatures,

- Hoelang de (moeilijk vervulbare) vacatures open staan,

- $\quad$ Oorzaak van de (moeilijk vervulbare) vacatures,

- Maatregelen genomen om de moeilijk vervulbare vacatures te verhelpen,

- Buitenlandse rekruteringsactiviteiten (redenen en verwachtingen toekomst),

- Werkdruk,

- Bezettingsgraad van arbeid,

- Oorzaak onderbezetting,

- $\quad$ Niet-gerealiseerde arbeidsplekken door tekort aan personeel,

- $\quad$ Rekrutering van personeel met onvoldoende vaardigheden (opleidingsniveau/-richting),

- Oorzaak rekrutering van personeel met onvoldoende vaardigheden.

\section{Samenvatting}

Afgestudeerden van een opleiding binnen de sector HBO chemie zijn wat vaker direct na het afstuderen een tijd werkloos dan de gemiddelde HBO-afgestudeerde. Echter, anderhalf jaar na afstuderen zijn ze minder vaak werkloos en hebben zij vaker een baan die qua niveau en qua richting goed aansluit op hun opleiding. Aangezien de intredeproblemen te maken kunnen hebben met het specifieke karakter van de opleiding, lijkt de arbeidsmarktpositie van de HBO afgestudeerde chemie daarom beter te zijn dan die van de gemiddelde HBO-afgestudeerde uit een andere richting. Deze relatief goede arbeidsmarktpositie heeft zich pas gedurende de laatste jaren ontwikkeld. Daarvoor was de positie van de afgestudeerden chemie met betrekking tot werkloosheid en werk vinden buiten de eigen vakrichting wat minder goed dan die van de gemiddelde andere HBO-afgestudeerde.

Bij de WO-afgestudeerden gelden soortgelijke conclusies. De AiO's buiten beschouwing gelaten, hebben de afgestudeerden chemie wat meer intredeproblemen maar vinden zij banen die beter aansluiten op de opleiding. De werkloosheid anderhalf jaar na afstuderen is vanaf 2000 lager dan in andere richtingen. Daarvoor was de werkloosheid hoog. Onderbenutting en werken in een andere richting zijn ook vooral na 2000 minder geworden. In 2003 hebben de WO'ers chemie voor het eerst sinds 1996 een hoger loon dan de andere WO'ers.

Chemiebedrijven blijken ten opzichte van bedrijven uit andere sectoren grotere problemen te hebben met het vinden van personeel. Zij hebben namelijk meer vacatures, die ook langer openstaan en moeilijker te vervullen zijn. Zij zoeken vaker 
dan andere bedrijven naar personeel in het buitenland, ervaren vaak een toegenomen werkdruk, kunnen vacatures minder goed vervullen, en moeten vaker personeel aannemen dat niet goed toegerust is om de taken te vervullen (te laag opleidingsniveau). Hierbij moeten voorzichtigheidshalve drie opmerkingen gemaakt worden. Ten eerste is het aantal bedrijven in de chemiesector vrij klein. Ten tweede is er alleen gekeken naar de situatie onder bedrijven ten tijde van de hoogconjunctuur in 2001, en ten derde kan er geen onderscheid gemaakt worden naar hoger en lager opgeleiden. Aangezien het voor werkgevers doorgaans gemakkelijker is om lager en middelbaar geschoolden te werven dan hooggeschoolden, zullen de resultaten echter eerder een onderschatting dan een overschatting zijn van de wervingsproblemen die werkgevers in de chemische sector ervaren.

Onze bevindingen geven aan dat er eerder een tekort aan afgestudeerden met een opleiding chemie is dan een tekort aan banen in de chemie. Voor de afgestudeerden die met een opleiding chemie op de arbeidsmarkt instromen lijkt dit waarschijnlijk niet zo te zijn omdat er een relatief hoge intredewerkloosheid onder de afgestudeerden van een opleiding chemie is. Een mogelijke verklaring van de hogere intredewerkloosheid is dat het zoeken naar een geschikte baan langer duurt bij afgestudeerden van specialistische opleidingen dan afgestudeerden van generieke opleidingen. Anderhalf jaar na afstuderen zijn deze intredeproblemen grotendeels verdwenen en hebben de afgestudeerden chemie een betere arbeidsmarktpositie dan afgestudeerden van andere richtingen.

\section{Opbouw rapportage}

De opbouw van deze rapportage is als volgt. Paragraaf 2 gaat in op de arbeidsmarktintrede van afgestudeerden met een opleiding in de chemie. Paragraaf 3 geeft een toelichting op de gebruikte databronnen. In paragraaf 4 wordt de arbeidsmarktpositie van de afgestudeerden met een opleiding in de chemie beschreven. Paragraaf 5 geeft informatie over de personeelsselectie door werkgevers van chemische bedrijven. De conclusies en suggesties voor verder onderzoek zijn in paragraaf 6 opgenomen. 



\title{
2 Data en definities
}

\author{
Enquêtes onder afgestudeerden
}

De gegevens die in deze paragraaf gebruikt worden, zijn afkomstig van de Schoolverlatersenquêtes van het ROA. In deze enquêtes worden personen anderhalf jaar na het afstuderen ondervraagd. Door het ROA worden jaarlijks drie grootschalige afgestudeerdenonderzoeken uitgevoerd die samen het Schoolverlaters Informatie Systeem (SIS) vormen. Deze schoolverlatersonderzoeken zijn gericht op het monitoren en analyseren van de bestemming van gediplomeerde schoolverlaters in het vervolgonderwijs en op de arbeidsmarkt. Het betreft de volgende onderzoeken:

- Registratie van Uitstroom en Bestemming van Schoolverlaters (RUBS). Dit is een onderzoek onder de afgestudeerden van het algemeen voortgezet onderwijs (AVO), het voorbereidend beroepsonderwijs (VMBO), de beroepsopleidende leerweg $(B O L)$ en de beroepsbegeleidende leerweg $(B B L)$ van het middelbaar beroepsonderwijs (MBO).

- De HBO-Monitor. Dit is een onderzoek onder de afgestudeerden van het Hoger Beroepsonderwijs (HBO).

- De WO-Monitor. Dit is een onderzoek onder de afgestudeerden van de Wetenschappelijk Onderwijs. Het ROA voert sinds 1991 op structurele basis onderzoeken onder afgestudeerden uit.

Sinds het uitvoeringsjaar 1996 wordt dit onderzoek uitgevoerd volgens een geïntegreerd model (SIS), waarbij één meetmoment en één kernvragenlijst wordt onderscheiden. Voor al deze afgestudeerdenonderzoeken geldt dat onderwijsinstellingen zelf aangeven of zij met (een deel van) hun afgestudeerden willen deelnemen. De RUBS-enquête wordt bij de scholen aangeboden onder verantwoordelijkheid van het ROA. De HBO-Monitor wordt bij de hogescholen aangeboden onder auspiciën van de HBO-Raad. De WO-Monitor vindt sinds 1998 in VSNU-verband plaats. Sinds dit meetjaar nemen dan ook alle reguliere universiteiten deel aan de WO-Monitor.

In de voorliggende rapportage wordt de arbeidsmarktmonitoring beperkt tot afgestudeerden van het HBO en WO. In 2003 hebben in totaal 22.071 respondenten met een HBO- of WO-opleiding de enquête ingevuld. In onderstaande tabellen is HBO chemie gedefinieerd als de aggregatie van de opleidingen $\mathrm{HBO}$ chemische technologie (67 respondenten), HBO chemie (154) en HBO chemische laboratoriumopleiding (6). WO Chemie is gedefinieerd als de aggregatie van WO scheikundige technologie en bioprocestechnologie (48), WO scheikunde (64), WO geochemie (3) en WO farmacochemie (5). De totale steekproefomvang is voor HBO chemie 227 en voor WO chemie 120 afgestudeerden. De resultaten zullen steeds worden vergeleken met HBO natuur en techniek (2.988 respondenten) en WO natuur en techniek (1.435 respondenten). 
Werkgeversenquête

Een mogelijkheid om de problemen die werkgevers ondervinden bij het aannemen van personeel te onderzoeken biedt het OSA-Arbeidsvraagpanel. Het OSA-Arbeidsvraagpanel is een tweejaarlijkse steekproef uit alle arbeidsorganisaties in Nederland met minimaal vijf werknemers. Als eenheid wordt hierbij de vestiging gehanteerd, en niet de gehele organisatie; eventuele nevenvestigingen tellen als zelfstandige eenheden. De steekproef is gestratificeerd naar sector en grootteklasse. Het panel bevat informatie van 34 chemiebedrijven (SBI-code 240000-250000). Vanwege dit geringe aantal bedrijven zullen de resultaten met enige voorzichtigheid moeten worden geïnterpreteerd. De enquête in de voorliggende rapportage heeft betrekking op het kalenderjaar 2001, omdat de gegevens van 2003 nog niet beschikbaar waren in de periode dat het onderzoek werd uitgevoerd. 


\section{De arbeidsmarktpositie van afgestudeerden met een opleiding in de chemie}

In de eerste paragraaf worden de arbeidsmarktindicatoren voor HBO- en WO-afgestudeerden in 2003 weergegeven. Vervolgens wordt in de tweede paragraaf de ontwikkeling van elke indicator over de tijd weergegeven.

\subsection{Arbeidsmarktindicatoren 2003}

HBO-afgestudeerden

Tabel 1

Maatschappelijke positie van HBO-afgestudeerden in procenten van het totaal

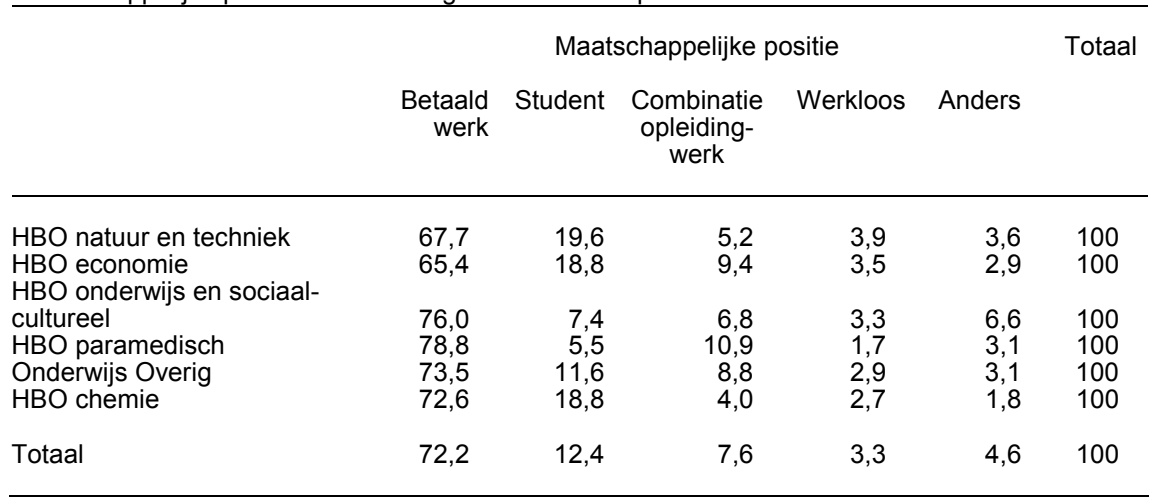

Bron: ROA Schoolverlatersenquêtes 2003

HBO-afgestudeerden chemie zijn in 2003 minder vaak werkloos dan afgestudeerden natuur en techniek van het HBO.

Tabel 2

Indicatoren arbeidsmarktpositie van HBO-afgestudeerden

HBO Chemie HBO Natuur HBO Totaal en techniek

Werkloos na afstuderen (\%)

Aantal maanden werkloos na afstuderen

Onderbenutting (\% werk op MBO-niveau of lager)

Niet eigen of verwante richting (\%)

Gemiddelde loon (bruto in $€$ )

12,6

Bron: ROA Schoolverlatersenquêtes 2003

Naast de huidige maatschappelijke positie van de afgestudeerden is er een aantal andere indicatoren die de ervaringen van afgestudeerden op de arbeidsmarkt weergeven. Tabel 2 geeft een overzicht van deze indicatoren. 
De belangrijkste conclusies voor HBO'ers chemie zijn:

- $\quad$ Zij zijn iets vaker werkloos geweest tussen het afstuderen en de eerste baan dan afgestudeerden uit andere opleidingen. Echter, HBO-afgestudeerden natuur en techniek zijn nog vaker werkloos geweest.

- $\quad$ HBO'ers chemie die werkloos zijn geweest na het afstuderen, zijn gemiddeld iets langer werkloos geweest dan de andere HBO' ers.

- Zij hebben veel vaker een baan op hun niveau dan de andere HBO' ers.

- $\quad \mathrm{Zij}$ hebben veel vaker een baan in hun eigen of verwante richting dan de andere HBO' ers.

- Het gemiddelde loon van HBO'ers chemie is lager.

WO-afgestudeerden

Tabel 3

Maatschappelijke positie van WO-afgestudeerden in procenten van het totaal

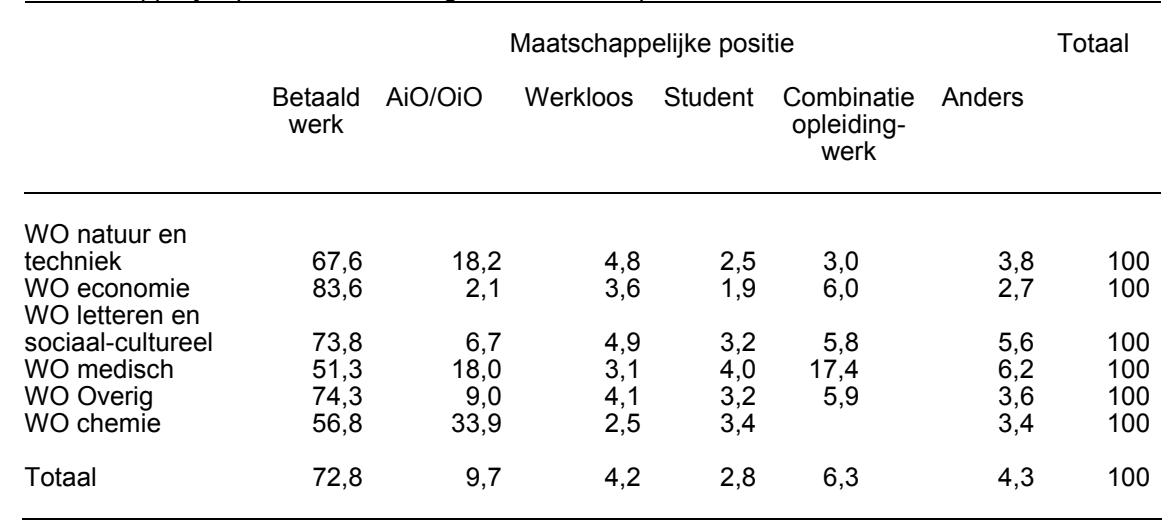

Bron: ROA Schoolverlatersenquêtes 2003

Zeer opvallend is dat ongeveer een derde van de WO-afgestudeerden chemie $\mathrm{AiO} / \mathrm{OiO}$ wordt. $\mathrm{Er}$ is maar een zeer klein aantal werkloos ten opzichte van de andere groepen afgestudeerden.

Op basis van tabel 4 kunnen de volgende conclusies voor WO-afgestudeerden chemie worden getrokken:

- Zij zijn vaker werkloos geweest na afstuderen dan de andere afgestudeerden van het WO.

- Zij zijn wat korter werkloos na afstuderen geweest dan de andere afgestudeerden van het WO.

- Zij hebben vaker een baan op het eigen niveau.

- Zij hebben vaker een baan in de eigen richting.

- Het gemiddelde loon van WO-afgestudeerden chemie is hoger dan dat van andere afgestudeerden uit de opleidingssector natuur en techniek, maar lager dan dat van de afgestudeerden op WO-niveau van andere richtingen. 
Tabel 4

Indicatoren arbeidsmarktpositie van WO-afgestudeerden

\begin{tabular}{lrrr} 
& WO Chemie & $\begin{array}{c}\text { WO natuur } \\
\text { en techniek }\end{array}$ & WO totaal \\
\hline Werkloos na afstuderen (\%) & 26,4 & 25,6 & 15,3 \\
Aantal maanden werkloos na afstuderen & 3,9 & 4,4 & 4,0 \\
Onderbenutting (\% werk op HBO-niveau of lager) & 21,6 & 34,0 & 35,3 \\
Niet eigen of verwante richting (\%) & 19,3 & 25,9 & 31,5 \\
Gemiddelde loon & 16,5 & 16,0 & 17,3 \\
& & & \\
\hline
\end{tabular}

Bron: ROA Schoolverlatersenquêtes 2003

Een groot deel van de WO'ers chemie wordt AiO. Deze groep afgestudeerden is een selectieve groep waarvan de opleiding bijna per definitie goed aansluit bij de werkzaamheden die ze uitoefenen. AiO's halen daarnaast gemiddeld hogere punten dan de andere studenten (gemiddeld tussen 7,5 en 8 ten opzichte van 7 tot 7,5 voor de studenten van andere richtingen). Daarom wordt in onderstaande tabel alleen de situatie bekeken voor de WO-afgestudeerden die niet AiO werden.

Tabel 5

Maatschappelijke positie van WO-afgestudeerden exclusief de AiO's, in procenten van het totaal

\begin{tabular}{lcccccr} 
& $\begin{array}{c}\text { Betaald } \\
\text { werk }\end{array}$ & Werkloos & Student & $\begin{array}{c}\text { Combinatie } \\
\text { opleiding- } \\
\text { werk }\end{array}$ & Anders & Totaal \\
\hline WO natuur en techniek & 83,6 & 5,5 & 3,0 & 3,5 & 4,4 & 100 \\
WO economie & 85,5 & 3,7 & 1,9 & 6,1 & 2,8 & 100 \\
WO letteren en sociaal- & 79,5 & 5,1 & 3,3 & 6,2 & 5,8 & 100 \\
cultureel & 63,5 & 3,7 & 4,9 & 20,5 & 7,4 & 100 \\
WO medisch & 85,5 & 3,9 & 5,3 & & 5,3 & 100 \\
WO chemie & 81,0 & 4,6 & 2,9 & 6,9 & 4,6 & 100 \\
Totaal & & & & & &
\end{tabular}

Bron: ROA Schoolverlatersenquêtes 2003

WO-afgestudeerden chemie zijn minder vaak werkloos dan de andere afgestudeerden.

Tabel 6

Indicatoren arbeidsmarktpositie WO-afgestudeerden exclusief de AiO's, in procenten van het totaal

WO Chemie WO Natuur en WO Totaal techniek

Werkloos na afstuderen (\%)

Aantal maanden werkloos na afstuderen

Onderbenutting (\% werk op HBO-niveau of lager)

Niet eigen of verwante richting (\%)

Gemiddelde loon (bruto in $€$ )

$\begin{array}{rr}26,8 & 15,2 \\ 4,6 & 4,1 \\ 42,3 & 39,6 \\ 30,7 & 34,5 \\ 17,0 & 17,8\end{array}$

Bron: ROA Schoolverlatersenquêtes 2003 
Belangrijkste conclusies voor WO-afgestudeerden chemie zijn:

- $\quad$ Zij zijn vaker werkloos geweest na afstuderen dan WO'ers van andere richtingen, maar WO-afgestudeerden natuur en techniek zijn nog vaker werkloos geweest.

- Ze hebben veel vaker een baan op het eigen niveau.

- Ze hebben ongeveer even vaak als WO-afgestudeerden natuur en techniek een baan in de eigen richting, maar vaker dan WO'ers van andere richtingen.

- Het gemiddeld loon is hoger dan dat van WO'ers van andere richtingen.

\section{Conclusie}

Het blijkt dat afgestudeerden chemie op HBO- en WO-niveau langer zoeken naar een baan, maar dat zij uiteindelijk een baan vinden die relatief goed aansluit op hun opleiding. Een verklaring hiervoor zou kunnen zijn dat afgestudeerden chemie (en ook andere richtingen binnen natuur en techniek) zodanig specifieke vaardigheden hebben dat het langer duurt voordat zij een baan vinden die goed aansluit bij hun opleidingsachtergrond.

\subsection{Ontwikkeling van arbeidsmarktindicatoren vanaf 1996}

\section{HBO-afgestudeerden}

In figuur 1 wordt de werkloosheidsontwikkeling over de afgelopen jaren getoond voor afgestudeerden van het $\mathrm{HBO}$.

Figuur 1

Werkloosheid anderhalf jaar na afstuderen, 1996-2003

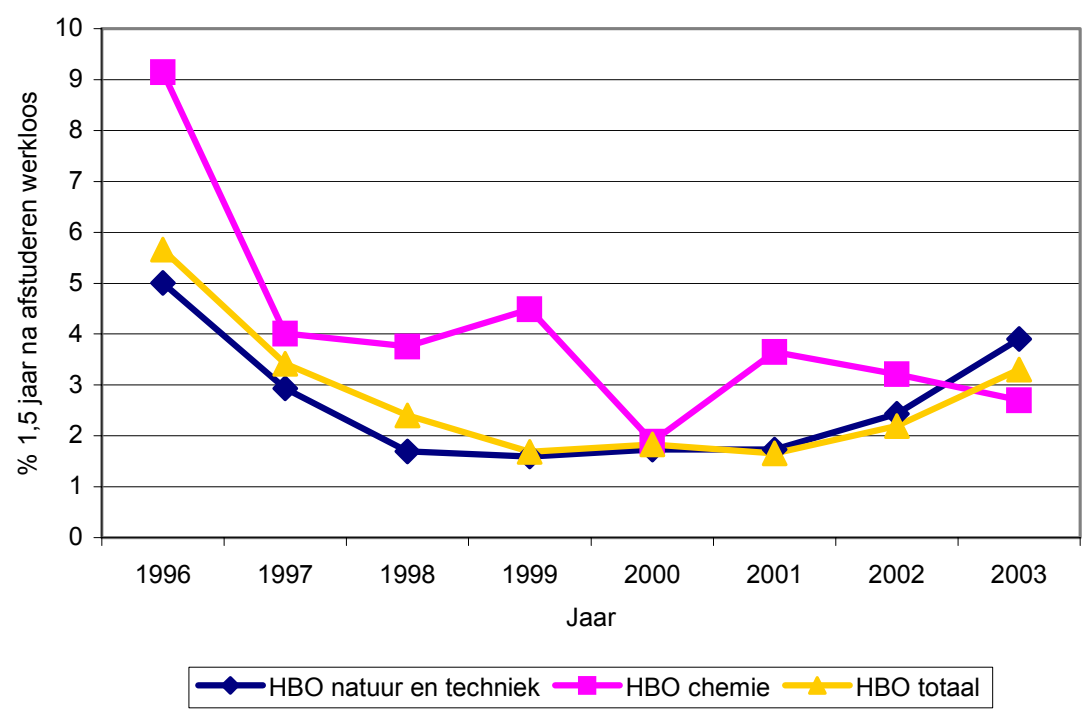

Bron: ROA Schoolverlatersenquêtes 
HBO-afgestudeerden chemie zijn van 1996 tot en met 2002 relatief vaak werkloos ten opzichte van de andere afgestudeerden op HBO-niveau.

In 2003 komt de werkloosheid voor het eerst wat lager uit voor de HBO-afgestudeerden chemie.

Figuur 2

Intredewerkloosheid HBO, 1999-2003

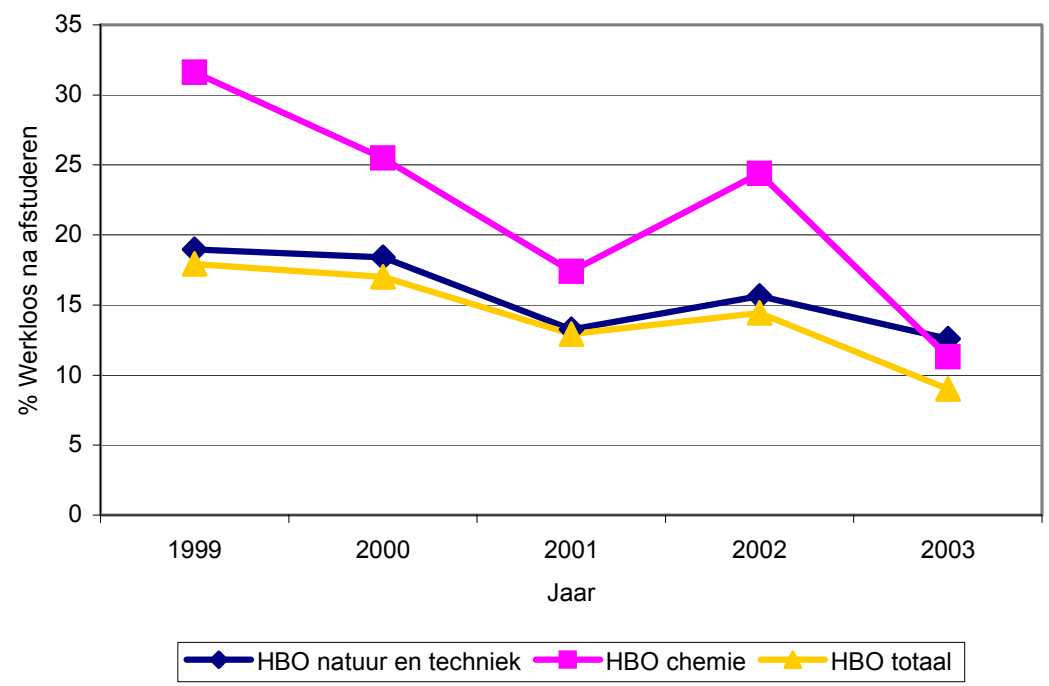

Bron: ROA Schoolverlatersenquêtes

De intredewerkloosheid is ook voor de HBO-afgestudeerden chemie hoger geweest gedurende de afgelopen jaren, en duikt in 2003 voor het eerst onder de intredewerkloosheid van de afgestudeerden van andere richtingen.

Het percentage afgestudeerden van een chemische opleiding dat een baan accepteert op een niveau lager dan HBO, is vanaf 1997 lager voor de technische opleidingen ten opzichte van de andere HBO-opleidingen. Chemie houdt gelijke tred met de andere technische studies, met uitzondering van het jaar 2003, waarin een aanzienlijke daling in de onderbenutting plaatsvindt. 
Figuur 3

Onderbenutting HBO 1996-2003

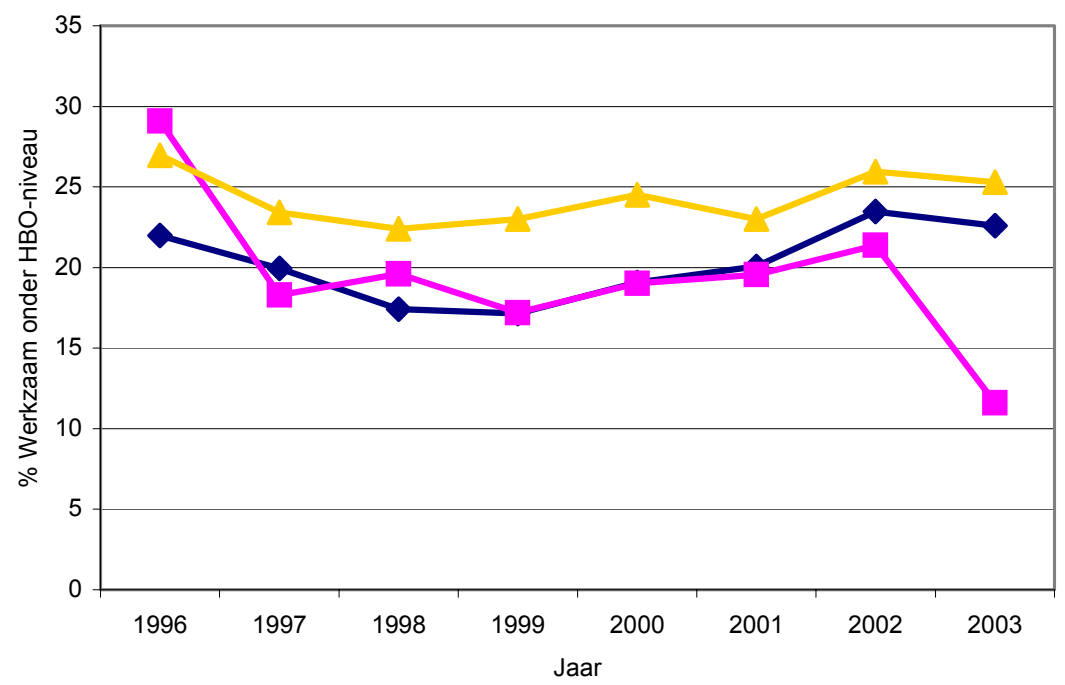

HBO natuur en techniek $-\mathrm{HBO}$ chemie $-\mathrm{HBO}$ totaal

Bron: ROA Schoolverlatersenquêtes

Figuur 4

Werk in andere richting HBO 1996-2003

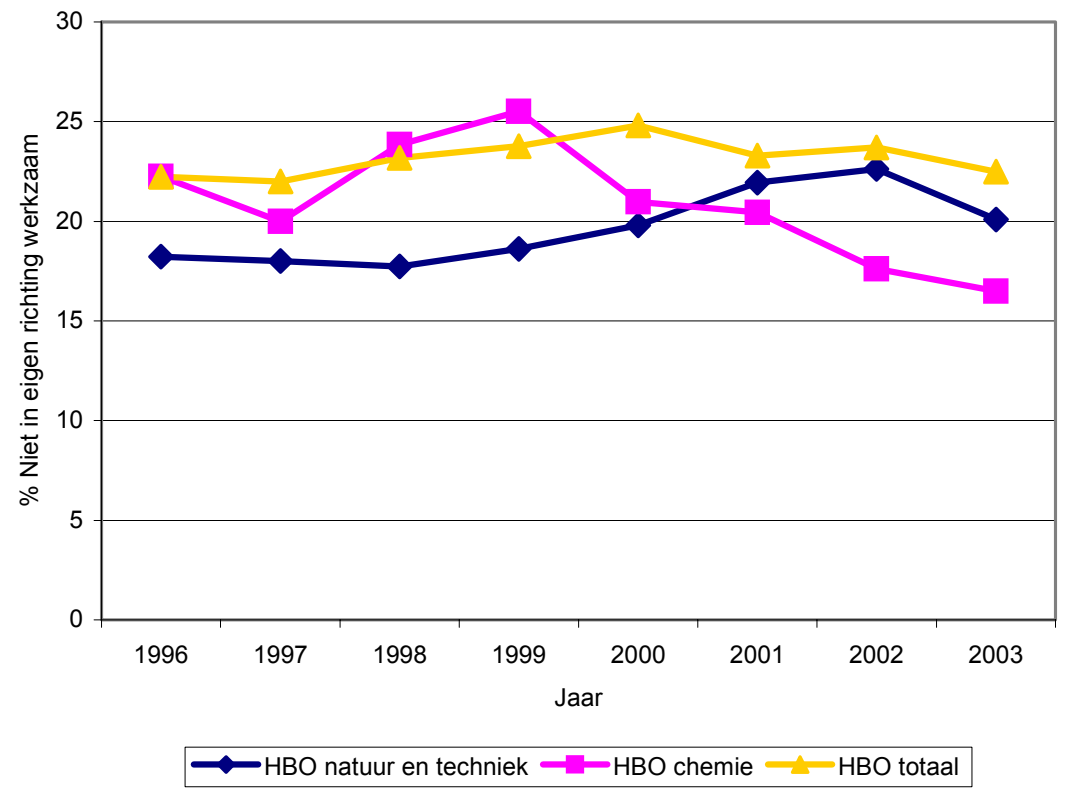

Bron: ROA Schoolverlatersenquêtes

12 


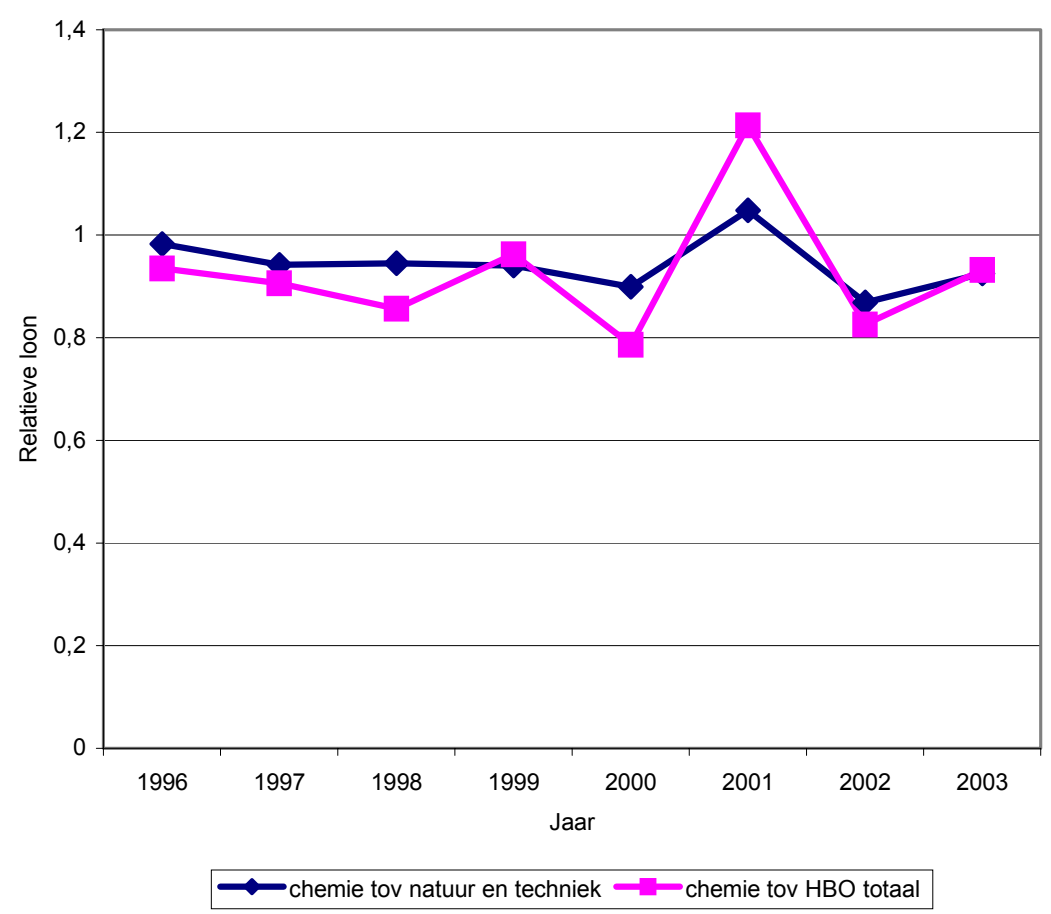

Bron: ROA Schoolverlatersenquêtes

Vanaf 2001 zijn er relatief minder afgestudeerden chemie werkzaam buiten het eigen beroependomein ten opzichte van andere afgestudeerden van een technische opleiding op HBO-niveau.

Het loon van HBO-afgestudeerden chemie is vrijwel over alle jaren lager dan dat van $\mathrm{HBO}-$ afgestudeerden van andere opleidingen.

\section{WO-afgestudeerden}

In de onderstaande figuren wordt de ontwikkeling van de arbeidsmarktpositie van WO-afgestudeerden chemie - exclusief de AiO's - getoond.

$\mathrm{Na}$ een periode van hoge werkloosheid in 1996 en 1997 heeft zich een een markante daling van de werkloosheid voorgedaan onder de WO'ers chemie. Vanaf 2000 duikt de werkloosheid onder het niveau van de overige WO'ers met een opleiding in natuur en techniek. De intredewerkloosheid onder de WO'ers chemie is de afgelopen jaren hoger geweest dan de werkloosheid onder WO'ers van andere richtingen. De intredewerkloosheid onder de WO'ers chemie is flink gedaald gedurende de laatste jaren. 
Figuur 6

Werkloosheid anderhalf jaar na afstuderen WO 1996-2003 exclusief AiO's

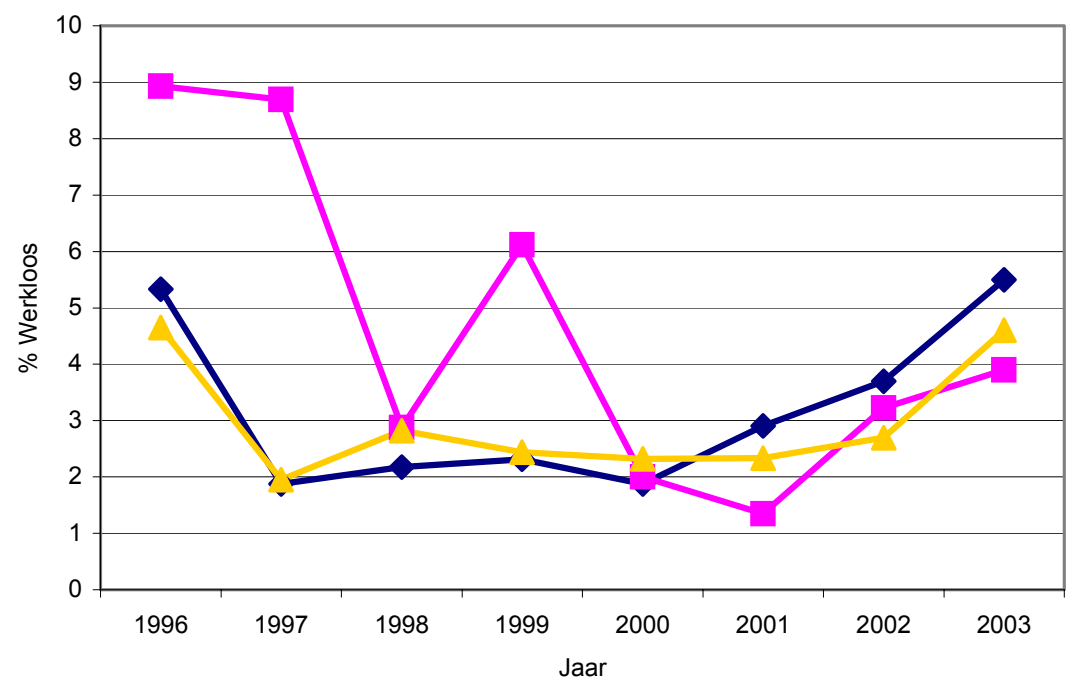

$\longrightarrow$ WO natuur en techniek - WO chemie - WO totaal

Bron: ROA Schoolverlatersenquêtes

Figuur 7

Intredewerkloosheid, WO 1996-2003 exclusief AiO's

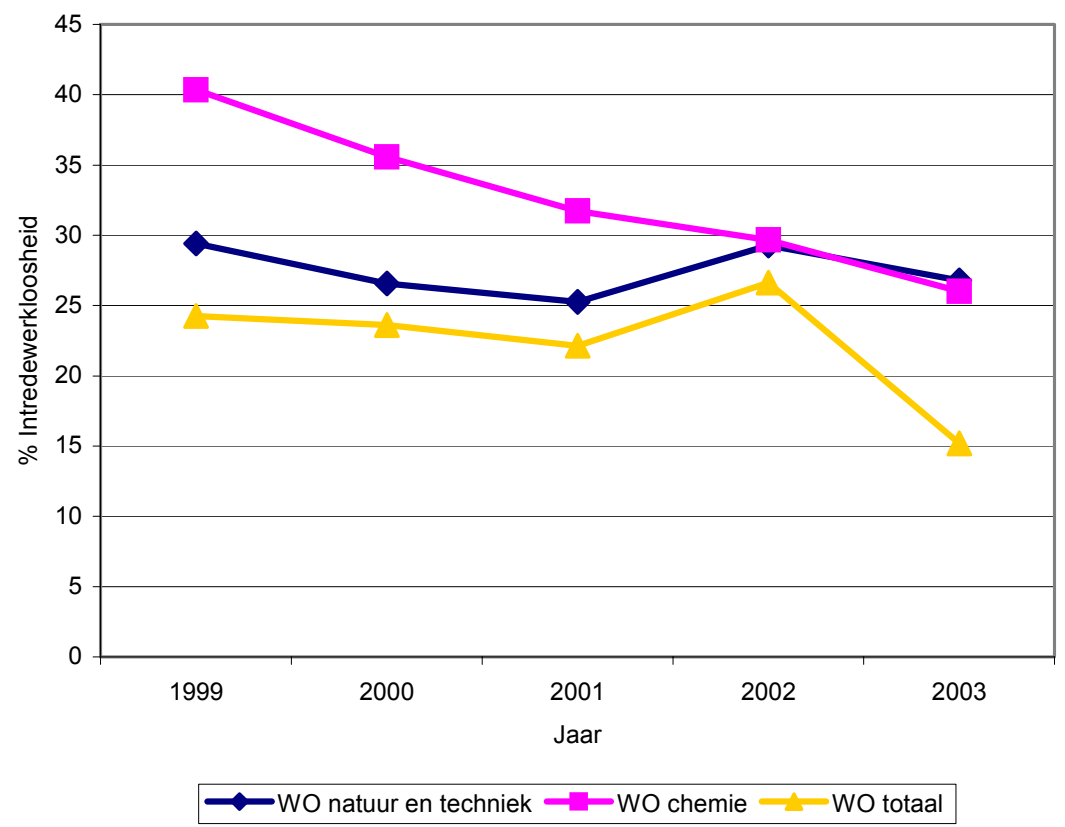

Bron: ROA Schoolverlatersenquêtes 
Figuur 8

Onderbenutting WO 1996-2003 exclusief AiO's

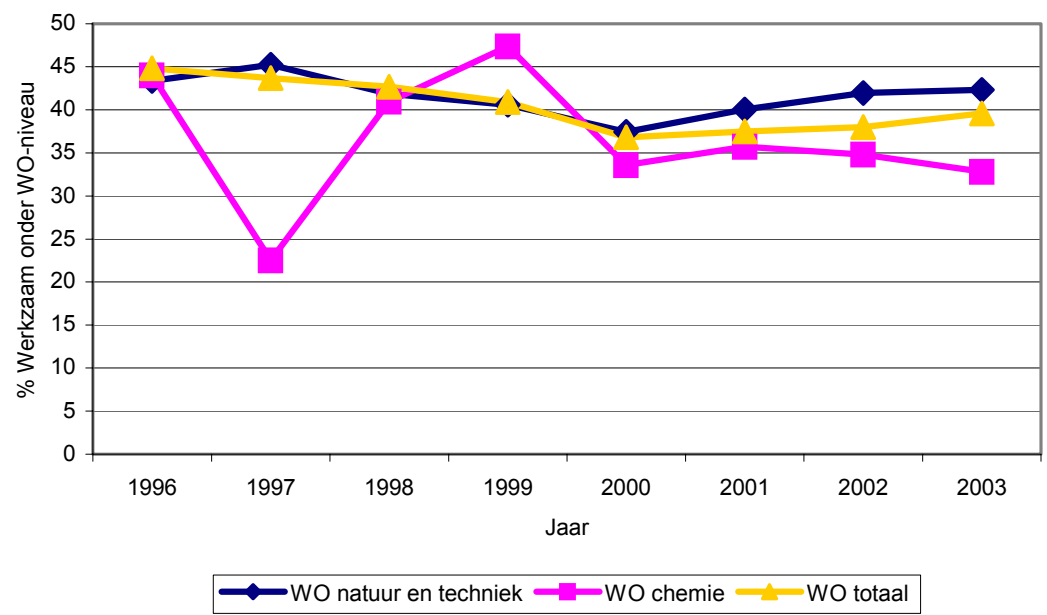

Bron: ROA Schoolverlatersenquêtes

Met uitzondering van 1999 is de onderbenutting lager onder de WO-afgestudeerden dan de onderbenutting onder de andere WO'ers.

Figuur 9

Werken in een andere richting WO 1996-2003 exclusief AiO's

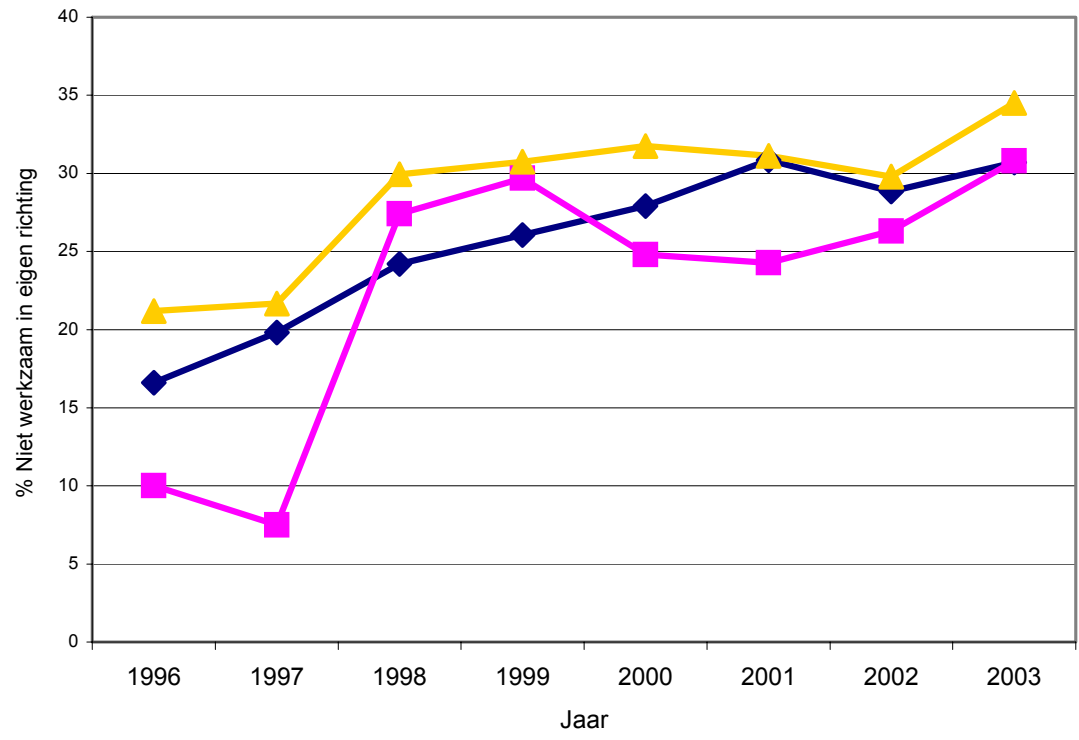

WO natuur en techniek - WO chemie - WO totaal

Bron: ROA Schoolverlatersenquêtes 
Het aantal WO'ers dat werkt in een andere richting is kleiner voor de opleiding chemie dan voor andere WO-opleidingen. Het percentage is echter wel toegenomen van 1996 tot 2003.

Figuur 10

Relatieve loon WO 1996-2003 exclusief AiO's

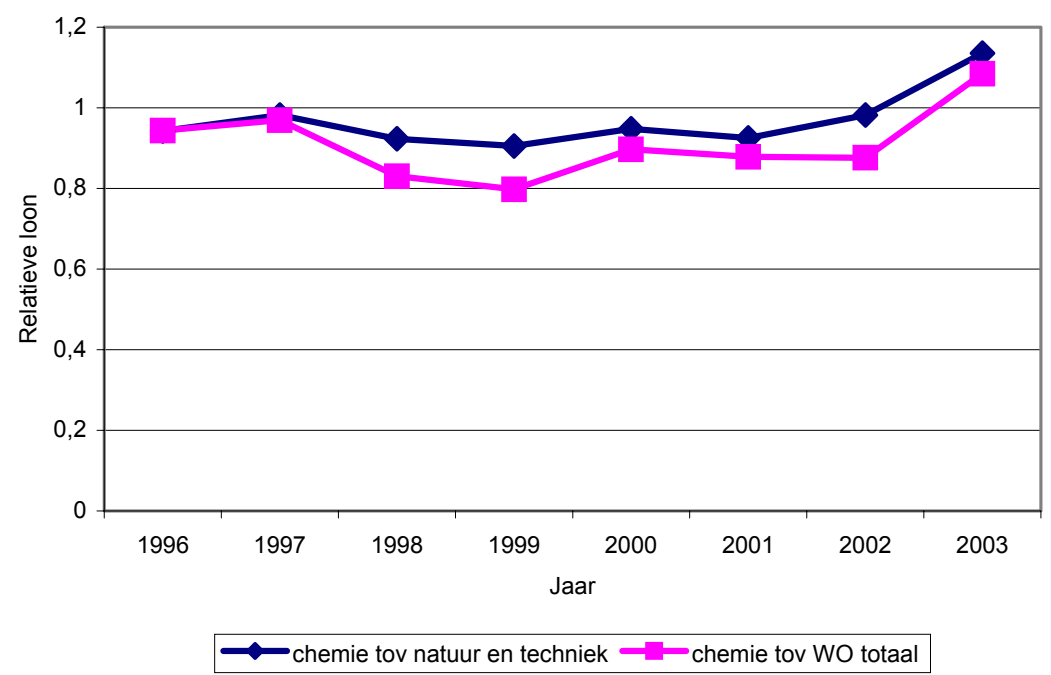

Bron: ROA Schoolverlatersenquêtes

Het relatieve loon stijgt in 2003 en daarmee verdienen de WO'ers chemie voor het eerst meer dan de WO'ers uit andere richtingen.

Conclusie

Hierboven is de ontwikkeling van de arbeidsmarktpositie van HBO- en WO-afgestudeerden met een opleiding in de chemie afgezet tegen afgestudeerden van andere richtingen voor de periode 1996-2003. Grofweg kan worden gesteld de arbeidsmarktpositie van afgestudeerden met een opleiding chemie duidelijk is verbeterd in deze periode. Niet alleen absoluut gezien voor de verschillende arbeidsmarktindicatoren, maar vanaf het jaar 2000 ook ten opzichte van andere opleidingen binnen en buiten de technische richtingen. Zo is de werkloosheid onder afgestudeerde HBO'ers en WO'ers met een opleiding in de chemie door de neergaande conjunctuur weliswaar gestegen van 2002 naar 2003, maar is de werkloosheid lager dan onder afgestudeerden van andere richtingen. Ook andere arbeidsmarktindicatoren wijzen op een duidelijke verbetering van de relatieve arbeidsmarktpositie gedurende de laatste jaren. 


\section{De vraag naar arbeidskrachten door werkgevers}

Aan de vraagzijde van de arbeidsmarkt geldt dat vraagoverschotten niet eenvoudig af te lezen zijn uit het aantal vacatures. Wanneer een werkgever er bijvoorbeeld niet in slaagt afgestudeerde chemici te rekruteren, kan hij mogelijk wel afgestudeerden met een andere opleidingsachtergrond of van een lager niveau aanstellen en deze om- of bijscholen. Daarnaast kan de werkgever besluiten minder te produceren en vacatures open te laten staan, de kwaliteitseisen te verlagen, een hoger salaris en betere secundaire arbeidsvoorwaarden te bieden, in het buitenland personeel te rekruteren of de werkdruk van het huidige personeel te verhogen.

In dit hoofdstuk wordt onderzocht in welke mate werkgevers in de chemiesector moeite hebben om de vacatures te vervullen en hoe zij hun personeelsselectie vormgeven en eventueel aanpassen aan de schaarste aan personeel.

\section{Opleidingsachtergrond van werkenden in de chemie}

In tabel 7 worden de belangrijkste opleidingstypen getoond voor de werkenden in de drie bedrijfssectoren van de chemische industrie. Uit de tabel wordt duidelijk dat de werkenden in de chemische sector zeker niet uitsluitend een opleiding chemie hebben afgerond, maar dat er ook veel schoolverlaters en afgestudeerden uit andere opleidingsrichtingen in de chemie werken.

Tabel 7

Belangrijkste opleidingstypen van de werkenden per bedrijfssector, gemiddelde 2001-2002

Bedrijfsector Opleidingstype $\quad \%$ Trend

1998-2002

Basischemie

Basischemie

Basischemie

Basischemie

Basischemie

Basischemie

Basischemie

Basischemie

Basischemie

Basischemie

Basischemie

Basischemie

Kunststofverwerking

Kunststofverwerking

Kunststofverwerking

Kunststofverwerking

Kunststofverwerking

Kunststofverwerking

Kunststofverwerking

Kunststofverwerking

Kunststofverwerking

Kunststofverwerking

Kunststofverwerking

Kunststofverwerking

Kunststofverwerking

Kunststofverwerking
MBO procestechniek

MBO werktuigbouw en mechanische techniek

MBO elektrotechniek

Basisonderwijs

VMBO theorie

WO wiskunde en natuurwetenschappen

MBO laboratorium

HAVO/VWO

HBO laboratorium

MBO facilitaire dienstverlening

VMBO mechanische techniek

Andere opleidingstypen

Basisonderwijs

VMBO theorie

HAVO/VWO

VMBO mechanische techniek

MBO werktuigbouw en mechanische techniek

MBO procestechniek

MBO administratie en logistiek

MBO elektrotechniek

VMBO bouwtechniek

VMBO administratie, handel en mode

MBO facilitaire dienstverlening

MBO handel

MBO bouw

Andere opleidingstypen
8,8 constant

5,8

5,7 constant

5,1

3,8

3,7

3,3

2,9 sterk dalend

2,9 dalend

2,7 sterk stijgend

2,6

36,3

15,0 constant

5,5 sterk dalend

5,3

4,8 dalend

4,3 constant

3,9 constant

3,8

3,7 constant

3,7

3,2

2,8

2,7 constant

2,6 sterk stijgend 
Tabel 7 (vervolg)

Belangrijkste opleidingstypen van de werkenden per bedrijfssector, gemiddelde 2001-2002

\begin{tabular}{llrl} 
Bedrijfssector & Opleidingstype & $\%$ Trend \\
& & $1998-2002$ \\
\hline & & \\
Eindproducten chemie & VMBO theorie & 6,8 dalend \\
Eindproducten chemie & MBO laboratorium & 6,6 sterk stijgend \\
Eindproducten chemie & Basisonderwijs & 6,6 & \\
Eindproducten chemie & HBO laboratorium & 6,0 dalend \\
Eindproducten chemie & MBO procestechniek & 5,9 \\
Eindproducten chemie & HAVO/WWO & 4,4 \\
Eindproducten chemie & WO wiskunde en natuurwetenschappen & 3,5 \\
Eindproducten chemie & MBO elektrotechniek & 3,3 \\
Eindproducten chemie & VMBO (uiterlijke) verzorging & 3,1 sterk stijgend \\
Eindproducten chemie & MBO administratie en logistiek & 2,7 sterk dalend \\
Eindproducten chemie & MBO handel & 2,5 \\
Eindproducten chemie & Andere opleidingstypen & 44,3
\end{tabular}

Bron: Enquête Beroepsbevolking, CBS

Tabel 8

Percentage werkenden naar opleidingsniveau, gemiddelde 2001-2002

$\begin{array}{llllll}\text { Bedrijfssector } & \text { BO } & \text { VMBO HAVO/VWO/ HBO WO }\end{array}$ $\mathrm{MBO}$

Tuinbouw

Veehouderij

Akkerbouw, bosbouw en visserij

Vlees- en visverwerking

Overige voedingsproducten

Drank en tabaksproducten

Basischemie

Eindproducten chemie

Kunststofverwerking

Basismetaal

Metaalproducten

Machine-industrie

Elektrotechniek

Transportmiddelen

Textiel

Hout- en bouwmaterialen

Papier

Grafische industrie

Energie

Bouw

Exploitatie van onroerend goed

Handel en reparatie

Scheep- en luchtvaart

Weg- en railvervoer

Communicatie

Bankwezen

Verzekeringswezen

Horeca

Zakelijke dienstverlening

Overige commerciële dienstverlening

Gezondheidszorg

Overige kwartaire diensten

Onderwijs

Overheid

Bedrijfssectoren totaal

BO VMBO HAVONO

HBO

Bron: Enquête Beroepsbevolking, CBS 
Tabel 8 toont dat in de chemiesector de opleidingsachtergrond van werkenden heel divers is. Kunststofverwerking blijkt relatief veel laag opgeleiden in dienst te hebben, Basischemie heeft veel middelbaar opgeleide werknemers in dienst en Eindproductenchemie heeft wat meer hoger opgeleide werknemers dan gemiddeld.

Vacatures

Tabel 9

Heeft uw organisatie op dit moment vacatures?

\begin{tabular}{lccc} 
& $\begin{array}{c}\text { Heeft organisatie op } \\
\text { dit moment } \\
\text { vacatures? }\end{array}$ & Totaal \\
& Ja & Nee & \\
\hline Voeding & 59,2 & 40,8 & 100 \\
Chemie & 73,5 & 26,5 & 100 \\
Metaal en elektrotechniek & 64,3 & 35,7 & 100 \\
Overige industrie & 49,5 & 50,5 & 100 \\
Energie & 54,5 & 45,5 & 100 \\
Bouw en onroerend goed & 60,0 & 40,0 & 100 \\
Handel en reparatie & 48,2 & 51,8 & 100 \\
Transport en communicatie & 47,9 & 52,1 & 100 \\
Bank- en verzekeringswezen & 76,5 & 23,5 & 100 \\
Horeca en zakelijke dienstverlening & 55,9 & 44,1 & 100 \\
Kwartaire diensten & 66,7 & 33,3 & 100 \\
Overheid en onderwijs & 59,1 & 40,9 & 100 \\
Overig & 60,1 & 39,9 & 100 \\
Totaal & 60,9 & 39,1 & 100 \\
& & & \\
\hline Bron: OSA Vraagpanel, & & &
\end{tabular}

Bron: OSA Vraagpanel, 2001

Relatief veel bedrijven in de chemiesector geven aan vacatures te hebben.

Tabel 10

Aantal vacatures als percentage van het personeel

\begin{tabular}{|c|c|c|c|c|}
\hline & $\begin{array}{c}\text { Openstaande } \\
\text { vacatures } \\
\%\end{array}$ & $\begin{array}{c}\text { Openstaande } \\
\text { vac. }>1 \text { jaar } \\
\%\end{array}$ & $\begin{array}{c}\text { Openstaande } \\
\text { vac. 3-12 mnd. } \\
\%\end{array}$ & $\begin{array}{c}\text { Openstaande } \\
\text { vac. 0-3 mnd. } \\
\%\end{array}$ \\
\hline Voeding & 3,7 & 2,7 & 1,7 & 2,6 \\
\hline Chemie & 7,8 & 15,6 & 3,6 & 3,2 \\
\hline \multicolumn{5}{|l|}{ Metaal en } \\
\hline elektrotechniek & 6,9 & 7,4 & 4,7 & 4,2 \\
\hline Overige industrie & 6,7 & 9,9 & 3,1 & 4,8 \\
\hline Energie & 9,0 & 11,7 & 5,1 & 5,5 \\
\hline Bouw en onroerend goed & 15,5 & 38,1 & 11,0 & 7,6 \\
\hline \multicolumn{5}{|l|}{ Transport en } \\
\hline $\begin{array}{l}\text { communicatie } \\
\text { Bank- en }\end{array}$ & 8,2 & 10,9 & 5,7 & 6,3 \\
\hline \multirow{6}{*}{$\begin{array}{l}\text { verzekeringswezen } \\
\text { Horeca en zakelijke } \\
\text { dienstverlening } \\
\text { Kwartaire diensten } \\
\text { Overheid en onderwijs } \\
\text { Overig } \\
\text { Totaal }\end{array}$} & 5,3 & 1,3 & 1,7 & 4,5 \\
\hline & 11,2 & 10,5 & 6,9 & 7,6 \\
\hline & 8,2 & 7,0 & 7,0 & 6,5 \\
\hline & 5,3 & 5,7 & 3,0 & 3,8 \\
\hline & 7,8 & 8,9 & 4,5 & 5,6 \\
\hline & 8,3 & 11,6 & 5,7 & 5,8 \\
\hline
\end{tabular}

Bron: OSA Vraagpanel, 2001 
Tabel 11

Oorzaken van openstaande vacatures

\begin{tabular}{|c|c|c|c|c|c|c|}
\hline & $\begin{array}{c}\text { Onvoldoende } \\
\text { beschikbaar } \\
\text { gekwalificeerd } \\
\text { personeel }\end{array}$ & $\begin{array}{l}\text { Lange procedures } \\
\text { werving en } \\
\text { selectie }\end{array}$ & $\begin{array}{c}\text { Bewust beleid } \\
\text { vacatures niet of } \\
\text { met vertraging op } \\
\text { vullen }\end{array}$ & $\begin{array}{l}\text { Te weinig } \\
\text { financiële } \\
\text { middelen }\end{array}$ & Andere oorzaak & Totaal \\
\hline $\begin{array}{l}\text { Voeding } \\
\text { Chemie } \\
\text { Metaal en elektrotechniek } \\
\text { Overige industrie } \\
\text { Energie } \\
\text { Bouw en onroerend goed } \\
\text { Handel en reparatie } \\
\text { Transport en communicatie } \\
\text { Bank- en verzekeringswezen } \\
\text { Horeca en zakelijke dienstverlening } \\
\text { Kwartaire diensten } \\
\text { Overheid en onderwijs } \\
\text { Overig } \\
\text { Totaal }\end{array}$ & $\begin{array}{l}70,6 \\
81,3 \\
84,2 \\
92,0 \\
73,9 \\
94,7 \\
81,0 \\
89,7 \\
73,3 \\
88,6 \\
85,0 \\
76,3 \\
85,3 \\
84,4\end{array}$ & $\begin{array}{r}11,8 \\
6,3 \\
5,3 \\
8,0 \\
1,3 \\
4,8 \\
6,9 \\
13,3 \\
1,3 \\
4,4 \\
9,6 \\
4,5 \\
4,9\end{array}$ & $\begin{array}{l} \\
4,8 \\
6,7 \\
6,3 \\
1,9 \\
7,0 \\
4,5 \\
3,4\end{array}$ & $\begin{array}{l}2,2 \\
0,9 \\
1,7 \\
1,2\end{array}$ & $\begin{array}{r}5,9 \\
6,3 \\
10,5 \\
26,1 \\
2,7 \\
9,5 \\
3,4 \\
6,7 \\
3,8 \\
6,6 \\
6,1 \\
4,0 \\
6,0\end{array}$ & $\begin{array}{l}100 \\
100 \\
100 \\
100 \\
100 \\
100 \\
100 \\
100 \\
100 \\
100 \\
100 \\
100 \\
100 \\
100\end{array}$ \\
\hline
\end{tabular}

Bron: OSA Vraagpanel, 2001 
Van de chemiebedrijven die aangeven vacatures te hebben is het aantal vacatures als percentage van het personeelsbestand gemiddeld. Zij hebben echter relatief veel langdurig openstaande vacatures. Van de bedrijven die aangeven vacatures te hebben die 3 maanden of langer open staan, zijn er relatief weinig chemiebedrijven die stellen dat zij vacatures hebben omdat er te weinig personeel is. Lange selectieprocedures en bewust beleid van vertraging worden door chemiebedrijven relatief vaak genoemd.

Moeilijk vervulbare vacatures

Tabel 12

Moeilijk vervulbare vacatures

\begin{tabular}{|c|c|c|c|}
\hline & \multicolumn{2}{|c|}{$\begin{array}{l}\text { Heeft organisatie op dit moment } \\
\text { moeilijk vervulbare vacatures? }\end{array}$} & \multirow[t]{2}{*}{ Totaal } \\
\hline & Ja & Nee & \\
\hline Voeding & 64,3 & 35,7 & 100 \\
\hline Chemie & 68,0 & 32,0 & 100 \\
\hline Metaal en elektrotechniek & 74,2 & 25,8 & 100 \\
\hline Overige industrie & 65,2 & 34,8 & 100 \\
\hline Energie & 69,4 & 30,6 & 100 \\
\hline Bouw en onroerend goed & 78,3 & 21,7 & 100 \\
\hline Handel en reparatie & 55,7 & 44,3 & 100 \\
\hline Transport en communicatie & 63,2 & 36,8 & 100 \\
\hline Bank- en verzekeringswezen & 57,7 & 42,3 & 100 \\
\hline Horeca en zakelijke dienstverlening & 63,8 & 36,2 & 100 \\
\hline Kwartaire diensten & 61,1 & 38,9 & 100 \\
\hline Overheid en onderwijs & 72,2 & 27,8 & 100 \\
\hline Overig & 64,0 & 36,0 & 100 \\
\hline Totaal & 64,7 & 35,3 & 100 \\
\hline
\end{tabular}

Bron: OSA Vraagpanel, 2001

Relatief veel chemiebedrijven geven aan moeilijk vervulbare vacatures te hebben.

Tabel 13

Moeilijk vervulbare vacatures als percentage van het personeel per bedrijf

\begin{tabular}{lr}
\hline & $\begin{array}{r}\text { Moeilijk vervulbare } \\
\text { vacatures } \\
\end{array}$ \\
\hline Voeding & 1,9 \\
Chemie & 8,7 \\
Metaal en elektrotechniek & 5,3 \\
Overige industrie & 5,8 \\
Energie & 6,3 \\
Bouw en onroerend goed & 45,1 \\
Handel en reparatie & 8,3 \\
Transport en communicatie & 6,6 \\
Bank- en verzekeringswezen & 2,1 \\
Horeca en zakelijke dienstverlening & 13,8 \\
Kwartaire diensten & 5,7 \\
Overheid en onderwijs & 4,5 \\
Overig & 7,1 \\
Totaal & 9,1 \\
\end{tabular}

Bron: OSA Vraagpanel, 2001 
Tabel 14

Oorzaak moeilijk vervulbare vacatures

\begin{tabular}{|c|c|c|c|c|c|c|c|}
\hline & $\begin{array}{c}\text { Te weinig } \\
\text { sollicitanten }\end{array}$ & $\begin{array}{l}\text { Genoeg } \\
\text { sollicitanten, } \\
\text { opleiding niet } \\
\text { passend }\end{array}$ & $\begin{array}{l}\text { Genoeg } \\
\text { sollicitanten, } \\
\text { nodige } \\
\text { ervaring } \\
\text { ontbreekt }\end{array}$ & $\begin{array}{c}\text { Genoeg } \\
\text { sollicitanten, te } \\
\text { hoge financiële } \\
\text { eisen }\end{array}$ & $\begin{array}{l}\text { Genoeg } \\
\text { sollicitanten, } \\
\text { afwijkende } \\
\text { arbeidstijden }\end{array}$ & Andere oorzaak & Totaal \\
\hline $\begin{array}{l}\text { Voeding } \\
\text { Chemie } \\
\text { Metaal en elektrotechniek } \\
\text { Overige industrie } \\
\text { Energie } \\
\text { Bouw en onroerend goed } \\
\text { Handel en reparatie } \\
\text { Transport en communicatie } \\
\text { Bank- en verzekeringswezen } \\
\text { Horeca en zakelijke dienstverlening } \\
\text { Kwartaire diensten } \\
\text { Overheid en onderwijs } \\
\text { Overig }\end{array}$ & $\begin{array}{l}68,4 \\
68,8 \\
51,1 \\
50,0 \\
56,0 \\
66,3 \\
71,7 \\
45,7 \\
46,7 \\
65,2 \\
69,1 \\
63,5 \\
60,6\end{array}$ & $\begin{array}{r}5,3 \\
12,5 \\
13,3 \\
23,3 \\
8,0 \\
15,7 \\
4,3 \\
8,6 \\
6,7 \\
12,0 \\
9,6 \\
9,6 \\
9,4\end{array}$ & $\begin{array}{r}10,5 \\
6,3 \\
17,8 \\
16,7 \\
8,0 \\
9,6 \\
10,9 \\
25,7 \\
13,3 \\
12,0 \\
5,7 \\
14,4 \\
10,8\end{array}$ & $\begin{array}{r}6,3 \\
4,4 \\
4,0 \\
1,2 \\
\\
13,3 \\
3,3 \\
1,7 \\
1,8 \\
3,3\end{array}$ & $\begin{array}{l}2,9 \\
1,1 \\
4,8 \\
1,4\end{array}$ & $\begin{array}{r}10,5 \\
6,3 \\
11,1 \\
10,0 \\
24,0 \\
7,2 \\
13,0 \\
17,1 \\
20,0 \\
6,5 \\
9,1 \\
10,8 \\
14,6\end{array}$ & $\begin{array}{l}100 \\
100 \\
100 \\
100 \\
100 \\
100 \\
100 \\
100 \\
100 \\
100 \\
100 \\
100 \\
100\end{array}$ \\
\hline Totaal & 64,2 & 10,3 & 10,2 & 2,2 & 2,3 & 10,8 & 100 \\
\hline
\end{tabular}

Bron: OSA Vraagpanel, 2001 
De moeilijk vervulbare vacatures als percentage van het personeelsbestand is in de chemie het grootst na de sectoren bouw en onroerend goed, en horeca en zakelijke dienstverlening.

De oorzaak van het moeilijk kunnen vervullen van de vacatures ligt er volgens de meeste chemiebedrijven aan dat er te weinig sollicitanten zijn. Ook geeft men meer dan gemiddeld aan dat de opleiding van de sollicitanten niet passend is of dat er te hoge eisen gesteld worden.

Tabel 15

Afgelopen twee jaar moeilijk vervulbare vacatures?

\begin{tabular}{lrrr} 
& Afgelopen 2 jaar moeilijk & Totaal \\
vervulbare vac.? & Ja & Nee & \\
\hline Voeding & 50 & 50 & 100 \\
Chemie & 67,6 & 32,4 & 100 \\
Metaal en elektrotechniek & 71,1 & 28,9 & 100 \\
Overige industrie & 60,6 & 39,4 & 100 \\
Energie & 46,3 & 53,7 & 100 \\
Bouw en onroerend goed & 59,2 & 40,8 & 100 \\
Handel en reparatie & 52,4 & 47,6 & 100 \\
Transport en communicatie & 44,5 & 55,5 & 100 \\
Bank- en verzekeringswezen & 67,6 & 32,4 & 100 \\
Horeca en zakelijke dienstverlening & 50,0 & 50,0 & 100 \\
Kwartaire diensten & 51,7 & 48,3 & 100 \\
Overheid en onderwijs & 65,4 & 34,6 & 100 \\
Overig & 57,3 & 42,7 & 100 \\
Totaal & 55,5 & 44,5 & 100 \\
\hline
\end{tabular}

Bron: OSA Vraagpanel, 2001

Chemiebedrijven hebben ook vaker dan gemiddeld moeilijk vervulbare vacatures gehad gedurende de afgelopen twee jaar.

Bedrijven in de chemiesector hebben om de vacaturevervulling te versnellen relatief vaak de wervingsinspanningen vergroot, de eisen aan de sollicitanten verlaagd of nieuwkomers opgeleid, en een hoger salaris geboden. Andere sectoren kiezen gemiddeld vaker voor het verbeteren van de secundaire arbeidsvoorwaarden of het aanpassen van de gemiddelde arbeidstijd. 
Tabel 16

Maatregelen om probleem van moeilijk vervulbare vacatures te verhelpen

\begin{tabular}{|c|c|c|c|c|c|c|c|c|}
\hline & $\begin{array}{c}\text { Wervings- } \\
\text { inspanning } \\
\%\end{array}$ & $\begin{array}{l}\text { Verlagen van } \\
\text { eisen } \\
\%\end{array}$ & $\begin{array}{c}\text { Opl. nieuw- } \\
\text { komers } \\
\%\end{array}$ & $\begin{array}{c}\text { Opleiden } \\
\text { personeel } \\
\%\end{array}$ & $\begin{array}{l}\text { Uitbesteden } \\
\text { werk } \\
\%\end{array}$ & $\begin{array}{c}\text { Hoger salaris } \\
\text { bieden } \\
\%\end{array}$ & $\begin{array}{c}\text { Arbeidstijd } \\
\text { aanpassen } \\
\%\end{array}$ & $\begin{array}{c}\text { Betere sec. } \\
\text { arbeids- } \\
\text { voorwaarden } \\
\%\end{array}$ \\
\hline $\begin{array}{l}\text { Chemie } \\
\text { Metaal en elektrotechniek } \\
\text { Overige industrie } \\
\text { Energie } \\
\text { Bouw en onroerend goed } \\
\text { Handel en reparatie } \\
\text { Transport en communicatie } \\
\text { Bank- en verzekeringswezen } \\
\text { Horeca en zakelijke dienstverlening } \\
\text { Kwartaire diensten } \\
\text { Overheid en onderwijs } \\
\text { Overig }\end{array}$ & $\begin{array}{l}91,3 \\
84,3 \\
87,7 \\
78,1 \\
78,7 \\
92,0 \\
71,7 \\
91,3 \\
88,1 \\
92,4 \\
90,6 \\
85,6\end{array}$ & $\begin{array}{l}26,1 \\
17,1 \\
19,3 \\
12,5 \\
19,6 \\
23,9 \\
28,3 \\
21,7 \\
20,1 \\
22,8 \\
17,5 \\
21,5\end{array}$ & $\begin{array}{l}65,2 \\
65,7 \\
57,9 \\
46,9 \\
68,2 \\
60,9 \\
50,9 \\
82,6 \\
64,2 \\
54,8 \\
45,1 \\
60,3\end{array}$ & $\begin{array}{l}52,2 \\
54,3 \\
50,9 \\
46,9 \\
50,5 \\
46,6 \\
30,2 \\
82,6 \\
51,9 \\
53,5 \\
51,7 \\
53,9\end{array}$ & $\begin{array}{l}34,8 \\
48,6 \\
42,1 \\
53,1 \\
61,7 \\
29,5 \\
30,2 \\
21,7 \\
39,6 \\
22,8 \\
36,5 \\
39,2\end{array}$ & $\begin{array}{l}43,5 \\
30,0 \\
26,3 \\
25,0 \\
38,3 \\
37,5 \\
37,7 \\
56,5 \\
37,3 \\
31,2 \\
33,2 \\
38,5\end{array}$ & $\begin{array}{l}17,4 \\
13,0 \\
10,5 \\
21,9 \\
10,3 \\
18,2 \\
18,9 \\
26,1 \\
17,9 \\
38,1 \\
25,0 \\
20,9\end{array}$ & $\begin{array}{l}26,1 \\
28,6 \\
22,8 \\
25,0 \\
37,7 \\
23,9 \\
24,5 \\
30,4 \\
31,3 \\
44,8 \\
32,6 \\
31,6\end{array}$ \\
\hline Totaal & 88,4 & 20,9 & 56,7 & 52,3 & 34,9 & 34,3 & 25,2 & 35,2 \\
\hline
\end{tabular}

Bron: OSA Vraagpanel, 2001 


\section{Buitenland}

Tabel 17

Buitenlandse rekruteringsactiviteiten

\begin{tabular}{|c|c|c|c|c|c|c|}
\hline & \multicolumn{3}{|c|}{$\begin{array}{l}\text { In buitenland gezocht naar } \\
\text { nieuw personeel? }\end{array}$} & \multicolumn{3}{|c|}{$\begin{array}{l}\text { In buitenland gezocht: nu } \\
\text { vaker dan vroeger? }\end{array}$} \\
\hline & $\mathrm{Ja}$ & Nee & Totaal & Ja & Nee & Totaal \\
\hline $\begin{array}{l}\text { Voeding } \\
\text { Chemie } \\
\text { Metaal en elektrotechniek } \\
\text { Overige industrie } \\
\text { Energie } \\
\text { Bouw en onroerend goed } \\
\text { Handel en reparatie } \\
\text { Transport en communicatie } \\
\text { Bank- en verzekeringswezen } \\
\text { Horeca en zakelijke dienstverlening } \\
\text { Kwartaire diensten } \\
\text { Overheid en onderwijs } \\
\text { Overig } \\
\text { Totaal }\end{array}$ & $\begin{array}{r}20,4 \\
21,2 \\
29,6 \\
22,1 \\
4,5 \\
7,2 \\
7,8 \\
5,9 \\
11,8 \\
6,7 \\
6,2 \\
3,7 \\
10,9 \\
8,5\end{array}$ & $\begin{array}{l}79,6 \\
78,8 \\
70,4 \\
77,9 \\
95,5 \\
92,8 \\
92,2 \\
94,1 \\
88,2 \\
93,3 \\
93,8 \\
96,3 \\
89,1 \\
91,5\end{array}$ & $\begin{array}{l}100 \\
100 \\
100 \\
100 \\
100 \\
100 \\
100 \\
100 \\
100 \\
100 \\
100 \\
100 \\
100 \\
100\end{array}$ & $\begin{array}{r}40,0 \\
42,9 \\
79,3 \\
71,4 \\
100,0 \\
84,6 \\
69,2 \\
71,4 \\
25,0 \\
44,4 \\
63,0 \\
62,5 \\
69,8 \\
65,7\end{array}$ & $\begin{array}{l}60,0 \\
57,1 \\
20,7 \\
28,6 \\
15,4 \\
30,8 \\
28,6 \\
75,0 \\
55,6 \\
37,0 \\
37,5 \\
30,2 \\
34,3\end{array}$ & $\begin{array}{l}100 \\
100 \\
100 \\
100 \\
100 \\
100 \\
100 \\
100 \\
100 \\
100 \\
100 \\
100 \\
100 \\
100\end{array}$ \\
\hline
\end{tabular}

Chemiebedrijven zoeken veel vaker dan gemiddeld personeel in het buitenland. Dit proces is al langer aan de gang.

Tabel 18

Werknemers uit het buitenland in dienst?

Werknemers uit het buitenland in dienst?

Totaal

\begin{tabular}{lccc} 
& Ja & Nee \\
\hline Voeding & & 53,1 & 100 \\
Chemie & 46,9 & 35,3 & 100 \\
Metaal en elektrotechniek & 64,7 & 48,5 & 100 \\
Overige industrie & 51,5 & 57,9 & 100 \\
Energie & 42,1 & 77,3 & 100 \\
Bouw en onroerend goed & 22,7 & 84,4 & 100 \\
Handel en reparatie & 15,6 & 73,9 & 100 \\
Transport en communicatie & 26,1 & 75,4 & 100 \\
Bank- en verzekeringswezen & 24,6 & 61,8 & 100 \\
Horeca en zakelijke dienstverlening & 38,2 & 74,1 & 100 \\
Kwartaire diensten & 25,9 & 69,1 & 100 \\
Overheid en onderwijs & 30,9 & 75,9 & 100 \\
Overig & 24,1 & 68,9 & 100 \\
Totaal & 31,1 & 70,3 & 100
\end{tabular}

Bron: OSA Vraagpanel, 2001

De chemiebedrijven hebben het hoogste percentage buitenlanders in dienst. 
Tabel 19

Personeel uit buitenland (\%)

\begin{tabular}{lrc} 
& $\begin{array}{c}\text { Personeel uit EU land } \\
\%\end{array}$ & $\begin{array}{c}\text { Personeel uit niet EU land } \\
\%\end{array}$ \\
& & \\
\hline Voeding & 12,0 & 8,0 \\
Metaie & 5,6 & 12,6 \\
Metaal en elektrotechniek & 10,5 & 7,9 \\
Overige industrie & 10,0 & 6,9 \\
Energie & 8,6 & 14,1 \\
Bouw en onroerend goed & 5,8 & 8,7 \\
Handel en reparatie & 13,8 & 9,2 \\
Transport en communicatie & 14,8 & 5,1 \\
Bank- en verzekeringswezen & 14,7 & 8,4 \\
Horeca en zakelijke dienstverlening & 4,6 & 7,0 \\
Kwartaire diensten & 6,2 & 6,3 \\
Overheid en onderwijs & 2,8 & 7,4 \\
Overig & 11,5 & 7,6 \\
Totaal & 8,1 & \\
\hline
\end{tabular}

Bron: OSA Vraagpanel, 2001

In de chemiesector werkt een relatief hoog percentage buitenlanders. Er komen vooral veel buitenlanders uit niet-EU landen.

Het internationale karakter wordt meer dan gemiddeld genoemd door bedrijven in de chemiesector als reden voor het aannemen van buitenlanders. Daarnaast wordt relatief vaak de krapte op de Nederlandse arbeidsmarkt als reden genoemd. Men neemt buitenlanders niet aan omdat deze goedkoper of productiever zijn in de chemiesector.

Tabel 20

Opleidingsniveau buitenlanders

\begin{tabular}{lcccr}
\hline & $\begin{array}{c}\text { Overwegend } \\
\text { hoog } \\
\text { opgeleid }\end{array}$ & $\begin{array}{c}\text { Overwegend } \\
\text { laag opgeleid }\end{array}$ & $\begin{array}{c}\text { Ongeveer } \\
\text { even vaak } \\
\text { hoog als laag }\end{array}$ & Totaal \\
\hline Voeding & 39,1 & 43,5 & 17,4 & 100 \\
Chemie & 27,3 & 31,8 & 40,9 & 100 \\
Metaal en elektrotechniek & 20,4 & 42,9 & 36,7 & 100 \\
Overige industrie & 12,5 & 70,0 & 17,5 & 100 \\
Energie & 20,0 & 53,3 & 26,7 & 100 \\
Bouw en onroerend goed & 17,9 & 57,1 & 25,0 & 100 \\
Handel en reparatie & 42,2 & 28,9 & 28,9 & 100 \\
Transport en communicatie & 23,3 & 50,0 & 26,7 & 100 \\
Bank- en verzekeringswezen & 53,8 & 15,4 & 30,8 & 100 \\
Horeca en zakelijke dienstverlening & 37,1 & 34,3 & 28,6 & 100 \\
Kwartaire diensten & 28,5 & 36,6 & 34,9 & 100 \\
Overheid en onderwijs & 46,9 & 23,5 & 29,6 & 100 \\
Overig & 32,8 & 40,7 & 26,6 & 100 \\
Totaal & 31,3 & 38,3 & 30,4 & 100 \\
\hline Bron: OSA Vraagpanel, 2001 & & & & \\
\hline
\end{tabular}

Bron: OSA Vraagpanel, 2001

De chemiebedrijven werven hun buitenlands personeel gespreid over de verschillende opleidingsniveaus. 
Tabel 21

Reden aannemen buitenlandse werknemers

\begin{tabular}{|c|c|c|c|c|c|c|}
\hline & $\begin{array}{l}\text { Het internationale } \\
\text { karakter van } \\
\text { onderneming }\end{array}$ & $\begin{array}{l}\text { De krapte op de } \\
\text { Ned. arbeidsmarkt }\end{array}$ & $\begin{array}{c}\text { De loonkosten } \\
\text { van buitenlandse } \\
\text { werknemers laag }\end{array}$ & $\begin{array}{l}\text { De buitenlandse } \\
\text { werknemers zijn } \\
\text { productiever }\end{array}$ & Anders & Totaal \\
\hline Voeding & 40,0 & 45,0 & & 5,0 & 10,0 & 100 \\
\hline Chemie & 44,4 & 55,6 & & & & 100 \\
\hline Metaal en elektrotechniek & 19,6 & 52,2 & 2,2 & 2,2 & 23,9 & 100 \\
\hline Overige industrie & 5,7 & 65,7 & & & 28,6 & 100 \\
\hline Energie & 20,0 & 45,0 & & & 35,0 & 100 \\
\hline Bouw en onroerend goed & 10,6 & 59,6 & 2,1 & 2,1 & 25,5 & 100 \\
\hline Handel en reparatie & 19,3 & 50,9 & & & 29,8 & 100 \\
\hline Transport en communicatie & 17,1 & 65,7 & & & 17,1 & 100 \\
\hline Bank- en verzekeringswezen & 50,0 & 28,6 & & & 21,4 & 100 \\
\hline Horeca en zakelijke dienstverlening & 15,9 & 51,2 & 1,2 & & 31,7 & 100 \\
\hline Kwartaire diensten & 13,7 & 42,6 & 0,2 & 0,4 & 43,0 & 100 \\
\hline Overheid en onderwijs & 21,6 & 36,2 & & 0,9 & 41,4 & 100 \\
\hline Overig & 27,5 & 42,9 & 1,6 & 1,1 & 26,9 & 100 \\
\hline Totaal & 18,8 & 45,7 & 0,6 & 0,7 & 34,2 & 100 \\
\hline
\end{tabular}

Bron: OSA Vraagpanel, 2001 
Tabel 22

Verwachtingen aangaande rekrutering buitenlandse werknemers van bedrijven die al buitenlanders in dienst hebben

Toename Totaal

ja nee

Voeding

\begin{tabular}{llll} 
Voeding & 69,6 & 30,4 & 100 \\
Chemie & 72,7 & 27,3 & 100 \\
Metaal en elektrotechniek & 77,6 & 22,4 & 100 \\
Overige industrie & 62,5 & 37,5 & 100 \\
Energie & 62,5 & 37,5 & 100 \\
Bouw en onroerend goed & 64,3 & 35,7 & 100 \\
Handel en reparatie & 70,5 & 29,5 & 100 \\
Transport en communicatie & 69,0 & 31,0 & 100 \\
Bank- en verzekeringswezen & 69,2 & 30,8 & 100 \\
Horeca en zakelijke dienstverlening & 69,1 & 30,9 & 100 \\
Kwartaire diensten & 82,8 & 17,2 & 100 \\
Overheid en onderwijs & 81,1 & 18,9 & 100 \\
Overig & 76,3 & 23,7 & 100 \\
Totaal & 76,3 & 23,7 & 100 \\
& & & \\
\hline
\end{tabular}

Bron: OSA Vraagpanel, 2001

Bedrijven in de chemiesector die al buitenlanders in dienst hebben zullen in de toekomst ongeveer even vaak als gemiddeld buitenlandse werknemers werven.

Tabel 23

Verwachtingen aangaande rekrutering buitenlandse werknemers van bedrijven die nog geen buitenlanders rekruteerden

Toename Totaal

ja nee

\begin{tabular}{llrl}
\hline & & & \\
Voeding & 16,0 & 84,0 & 100 \\
Chemie & 16,7 & 83,3 & 100 \\
Metaal en elektrotechniek & 14,6 & 85,4 & 100 \\
Overige industrie & 20,0 & 80,0 & 100 \\
Energie & 20,8 & 79,2 & 100 \\
Bouw en onroerend goed & 20,3 & 79,7 & 100 \\
Handel en reparatie & 19,8 & 80,2 & 100 \\
Transport en communicatie & 17,6 & 82,4 & 100 \\
Bank- en verzekeringswezen & 19,0 & 81,0 & 100 \\
Horeca en zakelijke dienstverlening & 16,8 & 83,2 & 100 \\
Kwartaire diensten & 26,6 & 73,4 & 100 \\
Overheid en onderwijs & 12,9 & 87,1 & 100 \\
Overig & 14,4 & 85,6 & 100 \\
& & & 100
\end{tabular}

Bron: OSA Vraagpanel, 2001

Bedrijven in de chemiesector die nog geen buitenlanders in dienst hebben verwachten iets vaker dan gemiddeld buitenlanders te gaan rekruteren. 
Werkdruk

Tabel 24

Werkdruk

Is werkdruk veranderd afgelopen 2 jaar

Totaal

\begin{tabular}{|c|c|c|c|c|}
\hline & Afgenomen & $\begin{array}{r}\text { Gelijk } \\
\text { gebleven }\end{array}$ & Toegenomen & \\
\hline Voeding & 20,4 & 38,8 & 40,8 & 100 \\
\hline Chemie & & 39,4 & 60,6 & 100 \\
\hline Metaal en elektrotechniek & 9,2 & 43,9 & 46,9 & 100 \\
\hline Overige industrie & 10,5 & 47,4 & 42,1 & 100 \\
\hline Energie & 4,5 & 47,8 & 47,8 & 100 \\
\hline Bouw en onroerend goed & 4,4 & 48,3 & 47,2 & 100 \\
\hline Handel en reparatie & 14,5 & 39,8 & 45,8 & 100 \\
\hline Transport en communicatie & 8,5 & 44,1 & 47,5 & 100 \\
\hline Bank-en verzekeringswezen & 5,9 & 32,4 & 61,8 & 100 \\
\hline Horeca en zakelijke dienstverlening & 5,2 & 43,1 & 51,7 & 100 \\
\hline Kwartaire diensten & 4,6 & 28,3 & 67,1 & 100 \\
\hline Overheid en onderwijs & 2,9 & 23,6 & 73,5 & 100 \\
\hline Overig & 6,0 & 37,1 & 56,9 & 100 \\
\hline Totaal & 5,8 & 34,6 & 59,5 & 100 \\
\hline
\end{tabular}

Bron: OSA Vraagpanel, 2001

In $61 \%$ van de bedrijven in de chemiesector is de werkdruk in de afgelopen twee jaar toegenomen. Alleen in de sectoren bank- en verzekeringswezen, kwartaire diensten en overheid en onderwijs heeft een dergelijke grote verschuiving plaatsgevonden.

Tabel 25

Bezetting arbeid

Bezetting van arbeid Totaal

Onderbezetting Overbezetting passende bezetting

\begin{tabular}{lrrrr}
\hline & & & & \\
Voeding & 26,5 & 8,2 & 65,3 & 100 \\
Chemie & 32,4 & 8,8 & 58,8 & 100 \\
Metaal en elektrotechniek & 41,8 & 9,2 & 49,0 & 100 \\
Overige industrie & 30,5 & 9,5 & 60,0 & 100 \\
Energie & 25,4 & 10,4 & 64,2 & 100 \\
Bouw en onroerend goed & 50,0 & 1,1 & 48,9 & 100 \\
Handel en reparatie & 31,3 & 4,2 & 64,5 & 100 \\
Transport en communicatie & 32,2 & 4,2 & 63,6 & 100 \\
Bank- en verzekeringswezen & 17,6 & 5,9 & 76,5 & 100 \\
Horeca en zakelijke dienstverlening & 32,3 & 4,5 & 63,2 & 100 \\
Kwartaire diensten & 35,6 & 2,7 & 61,8 & 100 \\
Overheid en onderwijs & 36,1 & 2,5 & 61,4 & 100 \\
Overig & 33,5 & 3,0 & 63,6 & 100 \\
Totaal & 34,9 & 3,6 & 61,5 & 100 \\
& & & & \\
\hline
\end{tabular}

Bron: OSA Vraagpanel, 2001

Hoewel bedrijven in de chemiesector relatief vaak (ten opzichte van andere sectoren) aangeven dat er sprake is van overbezetting van arbeid - dat wil zeggen teveel 
werknemers in dienst voor het werk dat verricht moeten worden -, is dit slechts een klein percentage van het totaal aantal bedrijven. Bijna $60 \%$ geeft aan dat de bezetting passend is.

Tabel 26

Oorzaak onderbezetting

\begin{tabular}{|c|c|c|c|c|c|c|}
\hline & $\begin{array}{r}\text { Onvoldoende } \\
\text { beschikbaar } \\
\text { gekwalificeerd } \\
\text { personeel }\end{array}$ & $\begin{array}{c}\text { Lange } \\
\text { proce- } \\
\text { dures } \\
\text { werving } \\
\text { en } \\
\text { selectie }\end{array}$ & $\begin{array}{c}\text { Bewust } \\
\text { beleid } \\
\text { vacatures } \\
\text { niet of met } \\
\text { vertraging } \\
\text { op vullen }\end{array}$ & $\begin{array}{l}\text { Te weinig } \\
\text { financiële } \\
\text { middelen }\end{array}$ & $\begin{array}{l}\text { Andere } \\
\text { oorzaak }\end{array}$ & Totaal \\
\hline Voeding & 76,9 & 7,7 & 7,7 & & 7,7 & 100 \\
\hline Chemie & 81,8 & & 9,1 & & 9,1 & 100 \\
\hline Metaal en elektrotechniek & 83,3 & & 4,8 & 2,4 & 9,5 & 100 \\
\hline Overige industrie & 78,6 & & 7,1 & & 14,3 & 100 \\
\hline Energie & 50,0 & 6,3 & 6,3 & & 37,5 & 100 \\
\hline Bouw en onroerend goed & 80,9 & 1,1 & 4,5 & 2,2 & 11,2 & 100 \\
\hline Handel en reparatie & 90,4 & & & 1,9 & 7,7 & 100 \\
\hline Transport en communicatie & 68,4 & 2,6 & 10,5 & 2,6 & 15,8 & 100 \\
\hline $\begin{array}{l}\text { Bank- en verzekeringswezen } \\
\text { Horeca en zakelijke }\end{array}$ & 83,3 & & & & 16,7 & 100 \\
\hline dienstverlening & 76,5 & 2,4 & 4.7 & 2,4 & 14,1 & 100 \\
\hline Kwartaire diensten & 71,8 & 1,5 & 2,5 & 12,5 & 11,7 & 100 \\
\hline Overheid en onderwijs & 63,2 & 6,9 & 7,6 & 7,6 & 14,6 & 100 \\
\hline Overig & 76,2 & 4,8 & 4,8 & 3,7 & 10,6 & 100 \\
\hline Totaal & 73,8 & 2,8 & 4,4 & 6,7 & 12,3 & 100 \\
\hline
\end{tabular}

Bron: OSA Vraagpanel, 2001

Bedrijven in de chemiesector die aangeven dat er onderbezetting is, kunnen vaak geen personeel werven dat voldoende gekwalificeerd is.

Overige aanpassingen aan wervingsproblemen

Tabel 27

Geen uitbreiding door tekort personeel?

Geen uitbreiding door tekort Totaal personeel?

ja nee

\begin{tabular}{|c|c|c|c|}
\hline Voeding & 2,0 & 98,0 & 100 \\
\hline Chemie & 23,5 & 76,5 & 100 \\
\hline Metaal en elektrotechniek & 15,3 & 84,7 & 100 \\
\hline Overige industrie & 13,7 & 86,3 & 100 \\
\hline Energie & 19,4 & 80,6 & 100 \\
\hline Bouw en onroerend goed & 39,4 & 60,6 & 100 \\
\hline Handel en reparatie & 12,0 & 88,0 & 100 \\
\hline Transport en communicatie & 7,6 & 92,4 & 100 \\
\hline Bank- en verzekeringswezen & 5,9 & 94,1 & 100 \\
\hline Horeca en zakelijke dienstverlening & 18,5 & 81,5 & 100 \\
\hline Kwartaire diensten & 12,3 & 87,7 & 100 \\
\hline Overheid en onderwijs & 11,5 & 88,5 & 100 \\
\hline Overig & 16,2 & 83,8 & 100 \\
\hline Totaal & 14,9 & 85,1 & 100 \\
\hline
\end{tabular}

Bron: OSA Vraagpanel, 2001 
Bedrijven in de chemiesector zien vaker dan gemiddeld af van uitbreiding van de capaciteit door een tekort aan personeel.

Tabel 28

Percentage niet-gerealiseerde arbeidsplaatsen

\begin{tabular}{lc}
\hline & $\begin{array}{c}\text { Niet gerealiseerde } \\
\text { arbeidsplaatsen } \\
\%\end{array}$ \\
\hline Voeding & 14,3 \\
Chemie & 22,8 \\
Metaal en elektrotechniek & 16,5 \\
Overige industrie & 15,1 \\
Energie & 23,8 \\
Bouw en onroerend goed & 33,1 \\
Handel en reparatie & 19,0 \\
Transport en communicatie & 17,1 \\
Bank- en verzekeringswezen & 6,3 \\
Horeca en zakelijke dienstverlening & 21,7 \\
Kwartaire diensten & 14,5 \\
Overheid en onderwijs & 9,9 \\
Overig & 17,5 \\
Totaal & 19,1 \\
\hline Bron: OSA Vraagpanel, 2001 &
\end{tabular}

Bron: OSA Vraagpanel, 2001

In de chemie geven relatief veel bedrijven aan dat er niet-gerealiseerde arbeidsplaatsen zijn.

Tabel 29

Personeel met andere opleiding qua niveau of richting dan vereist

\begin{tabular}{lc}
\hline & $\begin{array}{c}\text { Personeelsbestand niet } \\
\text { voldoende } \\
\text { toegerust } \\
\%\end{array}$ \\
\hline Voeding & 33,8 \\
Chemie & 29,3 \\
Metaal en elektrotechniek & 35,9 \\
Overige industrie & 29,6 \\
Energie & 33,3 \\
Bouw en onroerend goed & 29,5 \\
Handel en reparatie & 27,5 \\
Transport en communicatie & 32,8 \\
Bank- en verzekeringswezen & 35,8 \\
Horeca en zakelijke dienstverlening & 37,8 \\
Kwartaire diensten & 35,8 \\
Overheid en onderwijs & 34,4 \\
Overig & 33,2 \\
Totaal & 34,2 \\
\hline
\end{tabular}

Bron: OSA Vraagpanel, 2001

Bedrijven in de chemiesector hebben relatief weinig personeel in dienst dat niet goed toegerust is om de taken te verrichten. 
Tabel 30

Oorzaak niet goed toegerust zijn van personeel

\begin{tabular}{|c|c|c|c|c|c|c|}
\hline & \multicolumn{3}{|c|}{$\begin{array}{l}\text { Niet toegerust: te laag } \\
\text { opleidingsniveau }\end{array}$} & \multicolumn{3}{|c|}{$\begin{array}{l}\text { Niet toegerust: verkeerde } \\
\text { opleidingsrichting }\end{array}$} \\
\hline & $\mathrm{Ja}$ & Nee & Totaal & $\mathrm{Ja}$ & Nee & Totaal \\
\hline Voeding & 95 & 5 & 100 & 20 & 80 & 100 \\
\hline Chemie & 81,3 & 18,8 & 100 & 13,3 & 86,7 & 100 \\
\hline Metaal en elektrotechniek & 63,3 & 36,7 & 100 & 20,0 & 80,0 & 100 \\
\hline Overige industrie & 69,7 & 30,3 & 100 & 39,4 & 60,6 & 100 \\
\hline Energie & 47,4 & 52,6 & 100 & 36,8 & 63,2 & 100 \\
\hline Bouw en onroerend goed & 60,5 & 39,5 & 100 & 18,6 & 81,4 & 100 \\
\hline Handel en reparatie & 62,9 & 37,1 & 100 & 20,0 & 80,0 & 100 \\
\hline Transport en communicatie & 40,0 & 60,0 & 100 & 15,0 & 85,0 & 100 \\
\hline Bank- en verzekeringswezen & 46,2 & 53,8 & 100 & 7,7 & 92,3 & 100 \\
\hline Horeca en zakelijke dienstverlening & 45,2 & 54,8 & 100 & 27,4 & 72,6 & 100 \\
\hline Kwartaire diensten & 46,4 & 53,6 & 100 & 23,5 & 76,5 & 100 \\
\hline Overheid en onderwijs & 29,5 & 70,5 & 100 & 15,5 & 84,5 & 100 \\
\hline Overig & 47,6 & 52,4 & 100 & 21,8 & 78,2 & 100 \\
\hline Totaal & 48,9 & 51,1 & 100 & 22,3 & 77,7 & 100 \\
\hline
\end{tabular}

Bron: OSA Vraagpanel, 2001

Bedrijven in de chemiesector blijken vooral personeel aan te nemen met een te laag opleidingsniveau in plaats van personeel met een andere opleidingsrichting dan vereist.

Conclusie

Veel verschillende indicatoren wijzen erop dat bedrijven in de chemische industrie in 2001 meer dan gemiddeld last hadden van personeelstekorten dan bedrijven in andere sectoren. Deze indicatoren hadden betrekking op zowel de vacaturevervulling, als op het werven van buitenlands personeel en de toegenomen werkdruk. Daarnaast hebben chemische bedrijven vaker dan gemiddeld lager gekwalificeerd personeel aangenomen, of zelfs afgezien van het uitbreiden van de productie door de personeelstekorten. 


\title{
5 Conclusies en aanbevelingen voor vervolgonderzoek
}

\author{
Conclusies
}

Afgestudeerden van een opleiding binnen de sector HBO chemie zijn wat vaker direct na het afstuderen een tijd werkloos dan de gemiddelde HBO-afgestudeerde. Anderhalf jaar na afstuderen zijn ze echter minder vaak werkloos en hebben zij vaker een baan die qua niveau en qua richting goed aansluit op hun opleiding. Aangezien de intredeproblemen te maken kunnen hebben met het specifieke karakter van de opleiding, lijkt de arbeidsmarktpositie van de HBO-afgestudeerde chemie daarom beter te zijn dan die van de gemiddelde HBO-afgestudeerde uit een andere richting. Deze relatief goede arbeidsmarktpositie heeft zich pas gedurende de laatste jaren ontwikkeld. Daarvoor was de arbeidsmarktpositie van de afgestudeerden chemie gemeten naar werkloosheid en het vinden van werk buiten het eigen beroependomein wat minder goed dan die van de gemiddelde andere HBO'er.

Bij de WO-afgestudeerden gelden soortgelijke conclusies. De AiO's buiten beschouwing gelaten, hebben de afgestudeerden chemie wat meer intredeproblemen maar vinden zij banen die beter aansluiten op de opleiding. De werkloosheid anderhalf jaar na afstuderen is pas vanaf 2000 lager geworden. Daarvoor was de werkloosheid relatief hoog. Onderbenutting en werken in een andere richting zijn ook vooral na het jaar 2000 minder geworden. In 2003 hebben de WO'ers chemie voor het eerst sinds 1996 een hoger loon dan dat van WO'ers uit andere opleidingsrichtingen.

Chemiebedrijven blijken ten opzichte van bedrijven uit andere sectoren grotere problemen te hebben bij het rekruteren van personeel. Zij hebben namelijk meer vacatures, die ook langer openstaan en moeilijker te vervullen zijn. Zij zoeken vaker dan andere bedrijven naar personeel in het buitenland, ervaren vaak een toegenomen werkdruk, kunnen vacatures minder goed vervullen, en moeten vaker personeel aannemen dat niet goed toegerust is om de taken te vervullen (te laag opleidingsniveau). Hierbij moeten voorzichtigheidshalve twee opmerkingen gemaakt worden. Ten eerste is het aantal bedrijven in de chemiesector vrij klein en ten tweede kan er geen onderscheid gemaakt worden naar hoger en lager opgeleiden. Aangezien het voor werkgevers doorgaans gemakkelijker is om lager en middelbaar geschoolden te werven dan hooggeschoolden, zullen de resultaten echter eerder een onderschatting dan een overschatting zijn van de problemen die werkgevers in de chemische sector ervaren bij het werven van afgestudeerden HBO'ers en WO'ers.

Deze bevindingen geven aan dat er eerder een tekort aan personeel is dan een tekort aan banen. Afgestudeerden die op de arbeidsmarkt instromen met een opleiding chemie kunnen echter de relatief hoge intredewerkloosheid ervaren als een tekort aan banen. Een oorzaak van deze intredewerkloosheid is dat het zoeken naar een geschikte baan langer duurt bij specialistische dan generalistische opleidingen. Anderhalf jaar na afstuderen zijn deze intredeproblemen grotendeels verdwenen en 
hebben de afgestudeerden chemie een betere arbeidsmarktpositie dan andere afgestudeerden.

Toch is de bovenstaande verklaring niet geheel bevredigend, aangezien het specialistische karakter van een opleiding ook zou kunnen betekenen dat het op voorhand heel duidelijk is bij welke specifieke banen een dergelijke opleiding goed aansluit. In dat geval zou de baanzoekduur van afgestudeerden chemie juist relatief kort zijn, en zou de vacaturevervulling in de chemie sneller dan gemiddeld verlopen. Een andere verklaring voor de tragere vacaturevervulling in de chemie ten opzichte van andere sectoren, zou een strengere en langere selectieprocedure voor sollicitanten kunnen zijn. Juist in de chemie kunnen de bedrijfsrisico's groot kunnen zijn als werknemers slecht functioneren. ${ }^{2}$

\section{Vervolgonderzoek}

Het vanzelfsprekend mogelijk om de resultaten van het onderzoek onder afgestudeerden met een opleiding chemie en onder chemische bedrijven jaarlijks of tweejaarlijks te blijven rapporteren. Van belang is verder op te merken dat er gegevens van het OSA Vraagpanel zijn gebruikt van 2001, toen de arbeidsmarkt nog zeer krap was. De arbeidsmarktsituatie is inmiddels drastisch gewijzigd, maar de meest recente gegevens van 2003 waren ten tijde van het uitvoeren van het onderzoek nog niet beschikbaar. Daarnaast kan het afgestudeerdenonderzoek van het ROA worden gebruikt om extra vragenblokken op te nemen of kunnen er vervolgmetingen worden gehouden om het carrièrepatroon in beeld te brengen. Bovendien kunnen er ook andere instrumenten en arbeidsmarktgegevens worden gebruikt om de arbeidsmarkt voor de chemie nader te analyseren. Hieronder wordt een (niet uitputtende) opsomming gegeven van andere opties voor nader onderzoek.

(1) Op basis van de voorliggende rapportage lijkt het gewenst om nader onderzoek te verrichten naar de oorzaken van de relatief grote intredewerkloosheid. Hiervoor is de hypothese opgeworpen dat afgestudeerden met een specialistische opleiding mogelijk meer tijd nodig hebben om een baan te vinden die aansluit bij hun opleiding dan afgestudeerden met een generalistische opleiding. Hierover is in de wetenschappelijke literatuur echter weinig bekend. Overigens zou hetzelfde kunnen gelden voor bedrijven die specialisten proberen te werven: ook zij moeten personeel werven in niches van de arbeidsmarkt. Daarnaast zou als hypothese kunnen worden opgeworpen dat bedrijven in de chemische industrie voorzichtiger zijn met het aannemen van personeel - door bijvoorbeeld de risico's van foute beslissingen van niet voldoende gekwalificeerd personeel - en derhalve een langere en strengere personeelsselectie erop nahouden.

(2) Van de werkgeverskant wordt vaak het belang erkend van het schetsen van een aantrekkelijk beeld van chemie opleidingen voor zoveel mogelijk scholieren. Zeer belangrijk voor een sector is echter dat deze scholieren ook met het 
juiste beeld van een beroep aan een opleiding beginnen zodat zij ook na de opleiding nog geïnteresseerd zijn voor het beroep. Onderzoek onder HAVO/VWO-leerlingen met betrekking tot hun studie-keuzemotieven, spijt van de opleidingskeuze, imago van chemie opleidingen en de realiteitszin van het beroepsbeeld is daarom van groot belang.

(3) Onder de MBO-, HBO- of WO-afgestudeerden die een opleiding chemie kozen en scholieren die als alternatief de opleiding chemie hadden maar toch een andere opleiding gekozen hebben, kunnen verschillen in motieven voor de studiekeuze onderzocht worden. Door de groepen te vergelijken kan worden bepaald op welk vlak er meer informatie of actie nodig is om scholieren ertoe te bewegen om voor een opleiding te kiezen.

(4) Onder afgestudeerden kan onderzocht worden (i) verschillen in competenties tussen afgestudeerden met een zonder een chemische opleidingsachtergrond om te beoordelen of het studieprogramma van een opleiding in de chemie voldoende is ingespeeld op wat op de arbeidsmarkt wordt gevraagd, (ii) het carrièreverloop van schoolverlaters met een chemische opleidingsachtergrond, (iii) apart onderzoek over de arbeidsmarktpositie van promovendi in de chemische richting. Wat betreft het carrièreverloop van afgestudeerden is het mogelijk als vervolg op de enquêtes anderhalf jaar na afstuderen vervolgonderzoek te houden onder HBO'ers en WO'ers na bijvoorbeeld 3, 5 of 10 jaar na afstuderen. Ook met de enquêtes van het Koninklijk Instituut van Ingenieurs (KIvl) kan een beter zicht worden verkregen op het carrièrepatroon en de salarisontwikkeling van afgestudeerde ingenieurs. Hierbij zou de positie van ingenieurs met een scheikundige opleidingsachtergrond kunnen worden vergeleken met de positie van ingenieurs met een andere opleidingsachtergrond op de arbeidsmarkt.

(5) Theoretisch gezien is het aannemelijk dat de verspreiding van innovaties wordt gestimuleerd door contacten van hoger opgeleiden, waaronder gepromoveerden, in netwerken van kenniskringen en alumniverenigingen. Ook universiteiten en hogescholen zouden hierbij een belangrijke rol kunnen vervullen. Daarnaast spelen netwerken van bedrijven, multinationals, en internationale conferenties waarschijnlijk een belangrijke rol in research en development en bij de diffusie en adoptie van kennis. Onderzocht zou kunnen worden welk belang de genoemde netwerken in de praktijk hebben voor de concurrentiekracht van de chemische sector in Nederland en hoe belangrijk de concentratie van bedrijven en de (fysieke) afstand tussen individuen voor de kennisuitwisseling is.

(6) Aan de hand van een eigen onderzoek onder werkgevers in de chemie (eventueel via internet) kunnen de determinanten van een succesvol personeelsbeleid worden bepaald. Hierbij speelt een rol in welke mate werkgevers in de chemie erin slagen hun vacatures op een adequate wijze te vervullen. Dit kan

2. Hiervoor worden enige aanwijzingen gevonden in ons onderzoek (zie tabel 11). 
gebeuren door hetzij het aantrekken van personeel op de externe arbeidsmarkt, hetzij het werven en opleiden van personeel op de interne arbeidsmarkt. Hierbij is nader onderzoek vereist naar de in- en uitstroom van personeel, de vacaturevervulling, het werving- en selectiebeleid, het scholingsbeleid, de arbeidsvoorwaarden en de functie-inhoud, het carrièreperspectief en het loopbaanbeleid. Voorts kan worden nagegaan hoe werkgevers denken over de opleiding chemie op scholen en universiteiten, en hoe zij de competenties van afgestudeerde chemici beoordelen.

(7) Tot slot willen we wijzen op de mogelijkheid om aan de hand van scenarioanalyses na te gaan welke kansen en bedreigingen voor chemie bedrijven zich op de lange termijn kunnen voordoen. Hierbij kunnen bijvoorbeeld veronderstellingen worden gemaakt ten aanzien van de concurrentiepositie van de chemische sector in Nederland ten opzichte van de chemie bedrijven elders in Europa of de wereld, en welke consequenties dit heeft voor de vraag naar chemici. Andere veronderstellingen die gemaakt kunnen worden hebben betrekking op de aantrekkelijkheid van een opleiding chemie of een baan in de chemie, en de consequenties daarvan voor de ontwikkeling van het aanbod van goed geschoolde chemici op de arbeidsmarkt op de lange termijn. Door de mogelijke toekomstige vraag- en aanbodontwikkelingen met elkaar te confronteren kan worden ingeschat welke scenario's zich op de arbeidsmarkt in de toekomst kunnen voordoen en in welke richting de oplossingen gezocht moeten worden. 